\title{
Multi-stage melt-rock interaction in the Mt. Maggiore (Corsica, France) ophiolitic peridotites: microstructural and geochemical evidence
}

\author{
Elisabetta Rampone - Giovanni B. Piccardo • \\ Albrecht W. Hofmann
}

Received: 29 November 2007/ Accepted: 10 March 2008/Published online: 7 April 2008

(C) Springer-Verlag 2008

\begin{abstract}
Spinel and plagioclase peridotites from the Mt.Maggiore (Corsica, France) ophiolitic massif record a composite asthenosphere-lithosphere history of partial melting and subsequent multi-stage melt-rock interaction. Cpx-poor spinel lherzolites are consistent with mantle residues after low-degree fractional melting $(F=5-10 \%)$. Opx + spinel symplectites at the rims of orthopyroxene porphyroclasts indicate post-melting lithospheric cooling $\left(T=970-1,100^{\circ} \mathrm{C}\right)$; this was followed by formation of olivine embayments within pyroxene porphyroclasts by melt-rock interaction. Enrichment in modal olivine (up to $85 \mathrm{wt} \%$ ) at constant bulk $\mathrm{Mg}$ values, and variable absolute REE contents (at constant LREE/HREE) indicate olivine precipitation and pyroxene dissolution during reactive porous melt flow. This stage occurred at spinel-facies depths, after incorporation of the peridotites in the thermal lithosphere. Plagioclase-enriched peridotites show melt impregnation microtextures, like opx + plag intergrowths replacing exsolved cpx porphyroclasts and interstitial gabbronoritic veinlets. This second melt-rock interaction stage caused systematic chemical changes in clinopyroxene (e.g. Ti, REE, Zr, Y increase), related to the concomitant effects of local melt-rock interaction at decreasing melt
\end{abstract}

Communicated by J. Hoefs.

Electronic supplementary material The online version of this article (doi:10.1007/s00410-008-0296-y) contains supplementary material, which is available to authorized users.

E. Rampone $(\bowtie) \cdot$ G. B. Piccardo

Dipartimento per lo Studio del Territorio e delle sue Risorse, University of Genova, Corso Europa 26, 16132 Genoa, Italy

e-mail: betta@dipteris.unige.it

\section{A. W. Hofmann}

Max Planck Institut für Chemie, Mainz, Germany mass, and crystallization of small $(<3 \%)$ trapped melt fractions. LREE depletion in minerals of the gabbronoritic veinlets indicates that the impregnating melts were more depleted than normal MORB. Preserved microtextural evidence of previous melt-rock interaction in the impregnated peridotites suggests that they were progressively uplifted in response to lithosphere extension and thinning. Migrating melts were likely produced by mantle upwelling and melting related to extension; they were modified from olivine-saturated to opx-saturated compositions, and caused different styles of melt-rock interaction (reactive spinel harzburgites, vs. impregnated plagioclase peridotites) depending on the lithospheric depths at which interaction occurred.

Keywords Melt-rock interaction - Melt impregnation · Reactive porous flow $\cdot$ Mantle peridotites .

Alpine-Apennine ophiolites

\section{Introduction}

Recent microstructural and geochemical studies on ophiolitic and abyssal peridotites have provided evidence that the compositional heterogeneity of the lithospheric mantle at extensional settings is not only induced by varying degrees and/or depth of partial melting. Rather, significant chemical modifications are caused by melt-rock interaction processes when the peridotites are incorporated in the thermal boundary layer (TBL) and in lithospheric environments (Kelemen et al. 1997; Niu et al. 1997; Rampone et al. 1997, 2004; Asimow 1999; Godard et al. 2000; Barth et al. 2003; Dijkstra et al. 2003; Müntener and Piccardo 2003; Niu 2004; Piccardo 2003; Piccardo et al. 2007; Seyler et al. 2007). The mechanisms and chemical 
consequences of melt-peridotite interaction can be highly variable depending on melt composition, melt-rock ratios and temperature contrasts between migrating melts and the host peridotite, the latter being mostly controlled by the lithospheric depth at which the interaction process occurs.

Porous flow percolation is thought to be the most common mechanism of melt migration from the asthenosphere towards the shallow lithospheric mantle (e.g. Maaløe and Scheie 1982; McKenzie 1984; Kelemen et al. 1992, 1995). Melt impregnation and refertilization of the lithospheric mantle is caused by the interstitial crystallization of percolating melts. This process leads to the formation of plagioclase- $( \pm \mathrm{px})$ rich peridotites, and it has been widely documented in abyssal (Hebert et al. 1983; Dick 1989; Cannat et al. 1990; Hekinian et al. 1993; Constantin et al. 1995; Seyler et al. 2001; Tartarotti et al. 2002; Chazot et al. 2005; von der Handt et al. 2006) and ophiolitic peridotites (e.g. Menzies 1973; Menzies and Allen 1974; Dick 1977; Jackson and Ohnenstetter 1981; Boudier and Nicolas 1977; Nicolas 1986, 1989; Tartarotti and Vaggelli 1995; Rampone et al. 1997; Dijkstra et al. 2001; Piccardo 2003; Piccardo et al. 2004, 2007; Müntener et al. 2004; Piccardo and Vissers 2007; Borghini et al. 2007).

On the other hand, a series of pioneering studies pointed out that asthenosphere-derived melts become progressively olivine-oversaturated and pyroxene-undersaturated during their upward migration. As a consequence, they are not in equilibrium with the country peridotite and interact with it, dissolving pyroxenes and precipitating olivine (Quick 1981; Kelemen 1990; Kelemen et al. 1992, 1995, 1997; Kelemen and Dick 1995). This process causes modal and bulk-chemical depletion in the lithospheric mantle, originating "reactive harzbugites" and replacive dunites. This has been documented in an increasing number of studies which have pointed that many depleted peridotites display peculiar structural-textural features and bulk vs. mineral chemistry contrasts, which cannot result from partial melting alone, rather they require a melt-rock interaction process (Van der Wal and Bodinier 1996; Niu 1997; Niu et al. 1997; Suhr et al. 1998; Asimow 1999; Dijkstra et al. 2001, 2003; Xu et al. 2003; Piccardo et al. 2004, 2007; Rampone et al. 2004; Godard et al. 2000; Seyler et al. 2007).

Different styles of depletion and/or refertilization of the lithospheric mantle by melt-rock interaction are consequence of the composition of migrating melts and the lithospheric depth at which the interaction occurs. Chemical and textural studies of melt-rock interaction processes in oceanic-type peridotites can thus shed light on the evolution and compositional heterogeneity of the lithospheric mantle at extensional settings. Insights on this topic have resulted from geochemical and microstructural investigations on the Alpine-Apennine ophiolitic peridotites, which are lithosphere remnants of the Jurassic Ligurian Tethys ocean (Rampone et al. 1997, 2004; Rampone and Piccardo 2000; Müntener and Piccardo 2003; Müntener et al. 2004; Piccardo 2003; Piccardo et al. 2004, 2007), and are considered to be on-land analogues to passive margin and ultra-slow spreading ridge environments (Rampone and Piccardo 2000; Piccardo 2008). Recent studies have revealed that the peridotites were affected by various stages of melt-rock interaction, which occurred at different lithospheric levels during their progressive exhumation towards the sea-floor, and caused significant chemical modifications of the lithospheric mantle protoliths (Rampone et al. 1997, 2004; Piccardo et al. 2004, 2007; Müntener and Piccardo 2003; Müntener et al. 2004; Borghini et al. 2007; Piccardo and Vissers 2007).

In this paper, we provide evidence for this multi-stage melt-rock reaction history, as recorded by the Mt.Maggiore (Corsica, France) ophiolitic peridotites, by combined microstructural, bulk and in situ mineral chemistry investigations on selected samples of spinel and plagioclasebearing impregnated peridotite, and a few gabbronoritic veinlets related to the impregnation event. Previous studies (Jackson and Ohnenstetter 1981; Rampone et al. 1997; Piccardo 2003) have pointed out that these peridotites experienced an "oceanic-type" evolution, namely asthenospheric upwelling and MORB-type melting, with subsequent cooling and accretion in a lithospheric environment. Textural and chemical evidence indicates that the peridotites underwent a multi-stage lithospheric exhumation, characterized by reactive melt migration, melt impregnation and multiple ultramafic-mafic intrusions. Aims of this work are to investigate (1) the origin and composition of migrating melts, (2) the chemical and modal changes induced, in the peridotites, by different melt-rock interaction processes and (3) the nature and conditions of melt-rock interactions.

\section{Field occurrence and samples studied}

The Corsica ophiolites are thought to represent fragments of the oceanic lithosphere of the Jurassic Ligurian Tethys ocean (Dal Piaz 1974). Peridotites and associated gabbroic rocks of the Mt.Maggiore (MM) massif have been interpreted as the deepest part of a reconstructed ophiolitic sequence outcropping in eastern Alpine Corsica (the "Schistes Lustres" composite nappe, see Fig. 1; Ohnenstetter et al. 1975; Jackson and Ohnenstetter 1981; Duran-Delga 1984; and references therein). The Mt.Maggiore (MM) massif mostly consist of variably depleted spinel and plagioclase-bearing peridotites, and minor mafic-ultramafic intrusive pods and dykes. The 


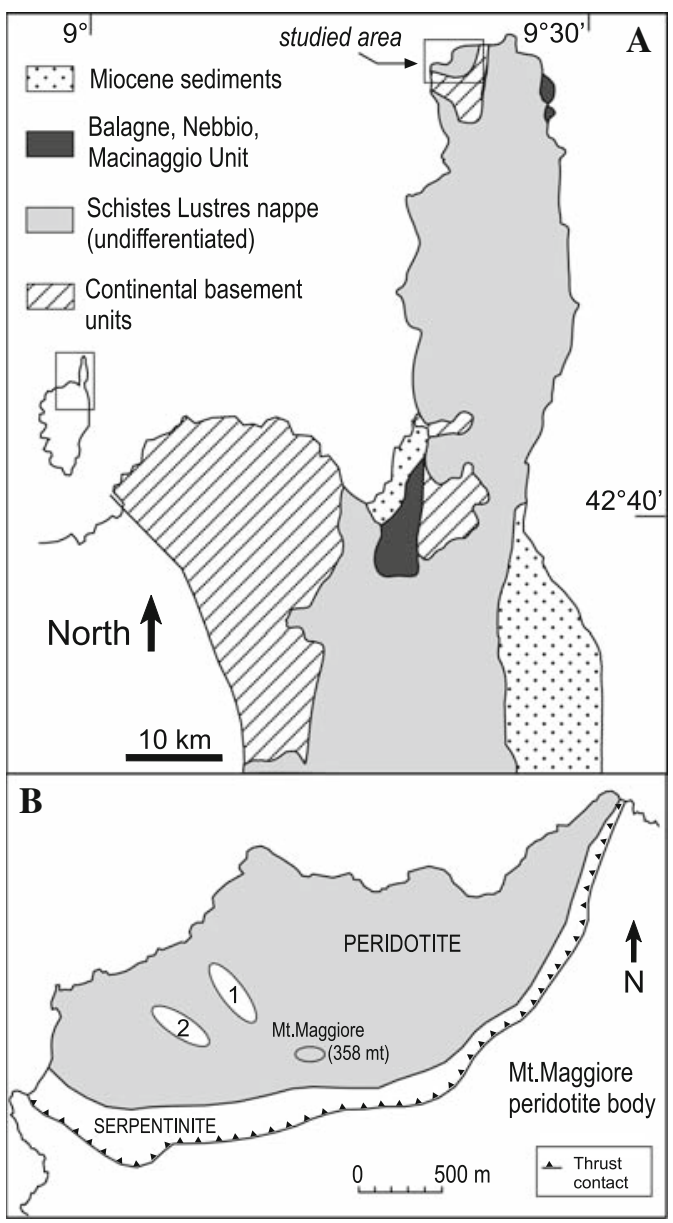

Fig. 1 a Tectonic sketch map of northern Corsica showing the main tectonic units (redrawn after Molli et al. 2006). Balagne, Nebbio, Macinaggio Units: ophiolitic and continental units. "Schists Lustres" composite nappe: ophiolitic sequences (mantle ultramafics, gabbros, pillow lavas and associated Jurassic to Cretaceous metasediments). Continental basement units: strongly deformed part of the Corsican continental margin. b The Mt.Maggiore peridotite body (redrawn after Jackson and Ohnenstetter 1981). 1 and 2 refer to sampling areas of MM1/4, MM1/5, MM1/9, MM1/10, MM1/11, C36, C221/2 (area 1) and MM2/5A,B, M10, M13, M14, MM2/11, MM2/12 (area 2), respectively

spinel peridotites are mainly cpx-poor lherzolites and harzburgites showing coarse-grained protogranular texture; in places, they grade into plagioclase-bearing peridotites (Fig. 2a). As previously documented (Rampone et al. 1997; Müntener and Piccardo 2003), field and textural evidence clearly indicates that plagioclase peridotites were originated by melt impregnation, rather than subsolidus recrystallization. Plagioclase mostly occurs as an interstitial phase between mantle olivine and pyroxenes (Fig. 2b, c), and often forms subparallel trails (Fig. 2d). The plagioclase amount in the peridotites is highly variable (up to more than $10 \mathrm{wt} \%$ ). In the most impregnated samples, plagioclase ( \pm clinopyroxene) trails are associated with plagioclase-rich gabbronoritic veinlets, which are often parallel to the trails orientation (Fig. 2d, e, f). In spite of the alignment of impregnationrelated features, the host peridotites are not deformed. Both spinel and plagioclase-bearing impregnated peridotites are locally cut and replaced by spinel dunites bodies and channels, which indicate focussed melt flow subsequent to diffuse melt migration (Müntener and Piccardo 2003) (Fig. 2b). The above structural features are crosscut by gabbroic dykes with MORB-type affinity (E. Rampone et al., in preparation). This paper is focused on the two stages of diffuse melt-rock interaction recorded in the Mt.Maggiore peridotites. Our samples are thus spinel peridotites, plagioclase-bearing peridotites and gabbronoritic veinlets related to melt impregnation; they were collected in the NW sector of Mt.Maggiore $\left(42^{\circ} 59^{\prime} 47^{\prime \prime} \mathrm{N}, 9^{\circ} 21^{\prime} 43^{\prime \prime} \mathrm{E}\right.$; Fig. 1), where the least serpentinized samples outcrop. Spinel peridotites (samples MM2/10, MM1/5, MM1/9, MM2/12, MM2/11, C221/2) display coarse-grained granular to low-strain tectonite texture and range from harzburgites to cpx-poor spinel lherzolites (modal cpx: 2.3-7.7 wt\%, Table 1). Plagioclase-bearing impregnated peridotites also exhibit granular texture and variable plagioclase modal amounts (4-6 wt\% in MM1/10, MM1/11, MM1/4, C36; up to $11 \mathrm{wt} \%$ in MM2/5A; see Table 1). In a few plagioclaserich peridotites (like MM2/5) we also collected some gabbronoritic segregations (samples M10, M13, M14; MM2/5B). They consist of thin (centimeter-scale) plagioclase-rich, opx-bearing veinlets and display irregular and fuzzy contacts towards the country rock (Fig. 2d, e, f).

\section{Petrography}

In the granular spinel peridotites, large mantle olivine (grain size $>0.5 \mathrm{~mm}$ ) are kinked and pyroxenes often display cleavage deformation and exsolutions, these latter being coarser and more diffuse in clinopyroxene; this indicates a weak internal plastic strain of the primary mineral assemblage. Spinel occurs both as single larger grains and in opx + spinel $( \pm \mathrm{cpx})$ symplectitic intergrowths mostly confined to the rims of large orthopyroxenes (Fig. 3a, b); these microstructures are better preserved in peridotites MM1/9, MM2/10 and MM1/5. Small pyroxenes in the $\mathrm{px}+$ spinel symplectites are mostly undeformed and not exsolved. Spinel peridotites also display melt-rock reaction microstructures, i.e. the crystallization of lobate olivine rims partly replacing exsolved ortho- and clino-pyroxene (Fig. 3c, d). This texture is particularly evident in sample MM2/11, in which exsolved orthopyroxenes display very irregular outlines and are in places dismembered and substituted by new undeformed olivine. It is remarkable that 
Fig. 2 a Spinel peridotite grading to impregnated plagioclase-bearing peridotite. b Dunite band replacive on impregnated plagioclase peridotite. c Impregnated peridotite significantly enriched in plagioclase. d Plagioclaserich iso-oriented trails in impregnated peridotite. e plagioclase-rich gabbronoritic veinlet in impregnated peridotite. $\mathbf{f}$ close-up of photograph (e), showing euhedral orthopyroxene (opx) and clinopyroxene in the plagioclase-rich veinlet
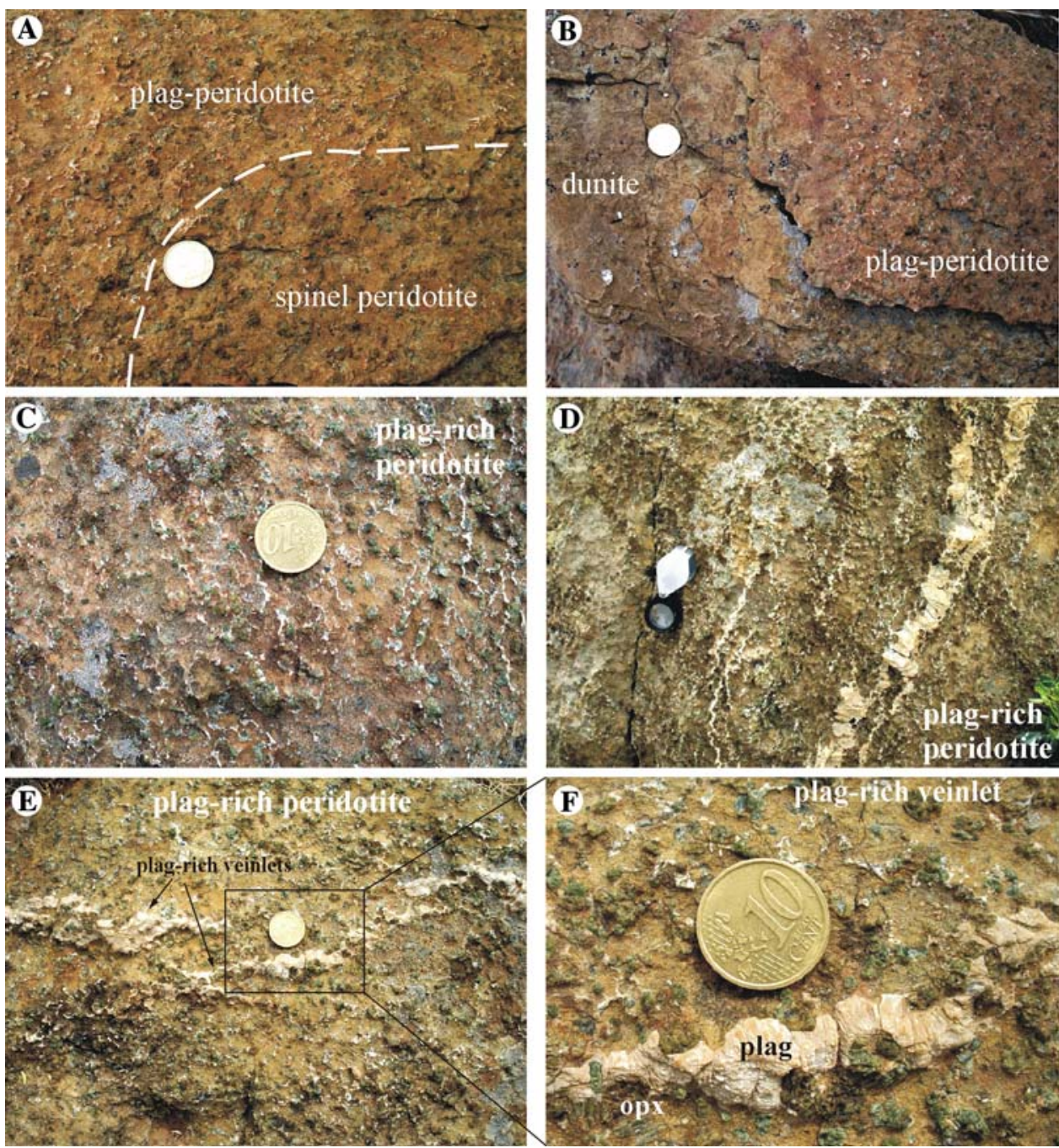

the replacement of olivine on orthopyroxene also occurs at the expense of opx + spinel symplectites (Fig. 3b).

The plagioclase peridotites also consist of a spinelbearing mantle assemblage, and in places preserve the $\mathrm{px}+$ spinel symplectites and the "olivine crystallizationpyroxene dissolution" microstructures documented in the spinel peridotites. In most samples, plagioclase is completely substituted by low-grade alteration products. Peculiar microstructures are indicative of melt impregnation and interaction of the peridotite matrix with percolating melts: (1) plagioclase blebs and/or veins interstitial between mantle minerals, (2) unstrained orthopyroxene and plagioclase intergrowths partially replacing exsolved and deformed mantle clinopyroxene (Fig. 3e, f), (3) crystallization of large unstrained poikilitic orthopyroxene grains that display irregular, lobate contacts and partially replace kinked mantle olivine (Fig. 3e, f). The poikilitic orthopyroxene often constitutes a single crystal in continuity with the orthopyroxene rim crystallized around mantle clinopyroxene. In the most impregnated peridotites (e.g. MM2/5A) clinopyroxene also crystallizes in association with plagioclase, within the gabbronoritic veinlets. It has subidiomorphic habit and differs from mantle clinopyroxene because it is undeformed and less exsolved; it often displays tiny rims, interstitial between plagioclase crystals. In the gabbronoritic veinlets, olivine rarely occurs in small euhedral crystals within pyroxenes, whereas larger kinked olivine grains are mostly confined to the host peridotites: they show lobate contacts, often marked by a thin opx rim, against the interstitial plagioclase of the veinlet. At the contact between host impregnated peridotites and gabbronoritic veinlets, large subidiomorphic orthopyroxene in the veinlet are often in continuity with opx rims around exsolved mantle clinopyroxene showing undulatory extinction and cleavage deformation. The two types of clinopyroxene, e.g. subidiomorphic "magmatic" cpx in the veinlet and deformed mantle cpx with opx reaction rim, are observable in a single thin section, at the veinlet-host peridotite interface. Textural evidence thus indicates that the impregnating melts crystallized both plagioclase and 
Table 1 Major element bulk-rock compositions of the Mt.Maggiore peridotites

\begin{tabular}{|c|c|c|c|c|c|c|c|c|c|c|}
\hline & \multicolumn{5}{|c|}{ Spinel peridotites } & \multicolumn{4}{|c|}{ Plagioclase peridotites } & \multirow{2}{*}{$\begin{array}{l}\text { Veinlet } \\
\text { M14 }\end{array}$} \\
\hline & MM1/5 & MM1/9 & MM2/12 & $\mathrm{MM} 2 / 10$ & MM2/11 & MM1/10 & MM1/11 & MM1/4 & $\mathrm{MM} 2 / 5 \mathrm{~A}$ & \\
\hline $\mathrm{SiO}_{2}$ & 41.41 & 42.60 & 41.17 & 41.60 & 39.99 & 41.78 & 41.28 & 40.87 & 41.21 & 43.56 \\
\hline $\mathrm{TiO}_{2}$ & 0.04 & 0.04 & 0.03 & 0.04 & 0.02 & 0.04 & 0.04 & 0.04 & 0.05 & 0.09 \\
\hline $\mathrm{Al}_{2} \mathrm{O}_{3}$ & 1.43 & 2.02 & 1.79 & 1.85 & 1.05 & 3.02 & 2.84 & 2.52 & 4.55 & 19.84 \\
\hline $\mathrm{Fe}_{2} \mathrm{O}_{3}$ & 8.48 & 8.55 & 8.88 & 9.12 & 9.12 & 8.39 & 8.47 & 8.46 & 8.08 & 3.95 \\
\hline $\mathrm{MnO}$ & 0.13 & 0.13 & 0.13 & 0.14 & 0.13 & 0.13 & 0.13 & 0.13 & 0.13 & 0.11 \\
\hline $\mathrm{MgO}$ & 40.78 & 39.72 & 41.25 & 40.66 & 42.77 & 39.29 & 39.62 & 39.32 & 36.29 & 16.95 \\
\hline $\mathrm{CaO}$ & 1.80 & 2.24 & 1.58 & 1.88 & 0.84 & 1.86 & 1.67 & 1.77 & 2.44 & 11.15 \\
\hline $\mathrm{Na}_{2} \mathrm{O}$ & $<0.10$ & $<0.10$ & $<0.10$ & $<0.10$ & $<0.10$ & $<0.10$ & $<0.10$ & $<0.10$ & 0.14 & 0.80 \\
\hline $\mathrm{K}_{2} \mathrm{O}$ & 0.00 & 0.00 & 0.00 & 0.00 & 0.00 & 0.00 & 0.00 & 0.00 & 0.00 & 0.02 \\
\hline L.O.I. & 5.88 & 4.65 & 5.1 & 4.77 & 5.63 & 5.9 & 6.24 & 7.14 & 7.06 & 3.25 \\
\hline Total & 99.96 & 99.93 & 99.92 & 100.07 & 99.56 & 100.41 & 100.30 & 100.25 & 99.85 & 99.72 \\
\hline Mg-number & 0.905 & 0.902 & 0.902 & 0.898 & 0.903 & 0.903 & 0.903 & 0.902 & 0.899 & 0.895 \\
\hline $\mathrm{Ni}(\mathrm{ppm})$ & 2,225 & 2,145 & 2,255 & 2,335 & 2,400 & 2,165 & 2,180 & 2,170 & 1,970 & 850 \\
\hline $\mathrm{Cr}(\mathrm{ppm})$ & 2,550 & 2,670 & 2,396 & 2,650 & 2,930 & 2,690 & 2,270 & 2,440 & 2,520 & 2,602 \\
\hline Sc (ppm) & 6 & 8 & 7 & 7 & 5 & 8 & 7 & 5 & 8 & \\
\hline \multicolumn{11}{|c|}{ Modes (wt\%) } \\
\hline $\operatorname{cpx}$ & 7.1 & 7.7 & 5.8 & 7.4 & 2.3 & 2.7 & 2.1 & 3.3 & 1.3 & 3.8 \\
\hline ol & 73.1 & 69.3 & 73.9 & 70.9 & 81.5 & 68.3 & 70.8 & 71.1 & 65.1 & 32 \\
\hline opx & 19 & 22.5 & 19.4 & 20.6 & 15.2 & 23.3 & 21.5 & 21.5 & 22.3 & 5.2 \\
\hline $\mathrm{sp}$ & 0.8 & 0.5 & 0.9 & 1.1 & 1 & & & & & \\
\hline plag & & & & & & 5.7 & 5.5 & 41.1 & 11.2 & 59 \\
\hline
\end{tabular}

Mg-number $=$ cationic ratio $\mathrm{Mg} /(\mathrm{Mg}+\mathrm{Fe})$. Modes have been computed by mass balance using the major element compositions of bulk rock and constitutent minerals

orthopyroxene, and likely reached clinopyroxene saturation in the veinlets.

\section{Bulk rock chemistry}

Details of the analytical procedures are given in Supplementary Appendix A. The spinel peridotites exhibit the largest major and trace element chemical variability (Tables 1, 2). They tend to define negative $\mathrm{SiO}_{2}-\mathrm{MgO}$ and positive $\mathrm{FeO}_{\text {tot }}-\mathrm{MgO}$ correlations, analogous to reconstructed compositional trends in the abyssal peridotites (Fig. 4). The lowest $\mathrm{SiO}_{2}$ and highest $\mathrm{FeO}$ contents are shown by sample MM2/11, i.e. the spinel peridotite displaying the most evident melt-rock interaction textures. Spinel peridotites also define the largest REE variation $(\mathrm{HREE}=0.4-1 \times \mathrm{C} 1)$ at slightly variable LREE/MREE fractionation $\left(\mathrm{Ce}_{\mathrm{N}} / \mathrm{Yb}_{\mathrm{N}}=0.010-0.034\right)$, and peridotite MM2/11 has the lowest HREE contents coupled to the least pronounced LREE depletion (Fig. 5a).

Plagioclase peridotites are characterized by higher $\mathrm{CaO}$, $\mathrm{Al}_{2} \mathrm{O}_{3}$ and lower $\mathrm{MgO}$ contents, relative to the spinel peridotites, and by high $\mathrm{Al}_{2} \mathrm{O}_{3} / \mathrm{CaO}$ ratios, exceeding the Primordial Mantle and Depleted Mantle values (Fig. 4).
Analogous chemical differences exist between impregnated plagioclase-rich and spinel peridotites from the Lanzo massif (Fig. 4b; data from Piccardo et al. 2007). Plagioclase peridotite $\mathrm{MM} / 5 \mathrm{~A}$ has the highest $\mathrm{Al}_{2} \mathrm{O}_{3}$ content (4.55 wt\%) and $\mathrm{Al}_{2} \mathrm{O}_{3} / \mathrm{CaO}$ ratio (1.86), in agreement with its high plagioclase modal abundance (11 wt $\%$, see Table 1). In terms of trace element chemistry, the plagioclase peridotites display slightly higher $\mathrm{Sr}$ abundances relative to spinel peridotites, the highest $\mathrm{Sr}$ content (3.69 ppm) in sample M2/5A; they also exhibit higher REE bulk concentrations $(\mathrm{HREE}=1.1-1.5 \times \mathrm{C} 1)$ although preserving similar LREE fractionation (Fig. 5a).

\section{Major and trace element mineral compositions}

Details of the analytical procedures are given in Supplementary Appendix A. In spite of the observed bulk rock heterogeneity, olivines in the peridotites display limited within and inter-sample chemical heterogeneity (Mg-number $=0.90-0.91)($ Supplementary Table 1). Clinopyroxene porphyroclasts in the spinel peridotites show rather homogeneous major (Mg-number $=0.89-0.91)$ and trace element compositions (Supplementary Table 2, Table 3), 

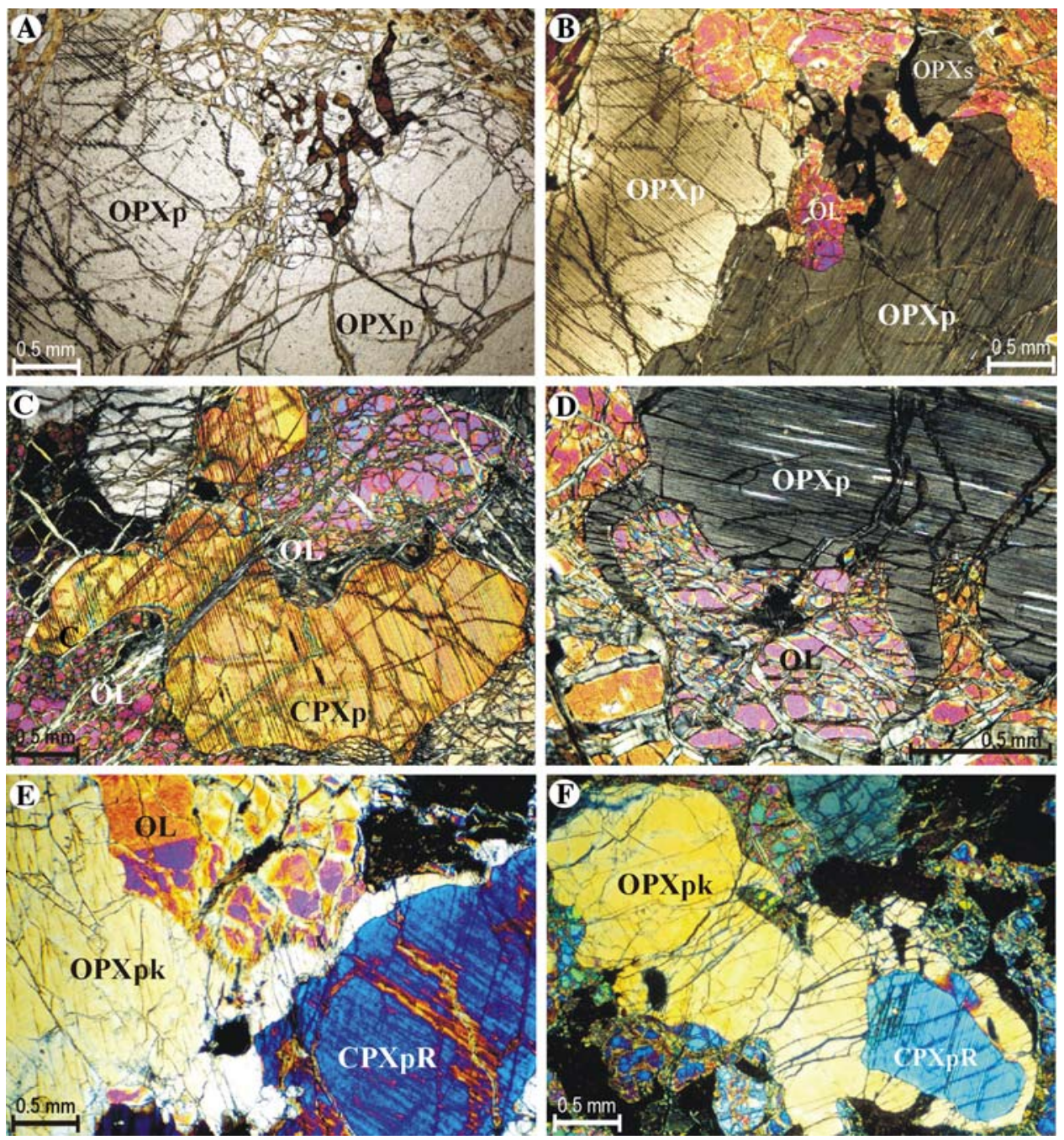

Fig. 3 Microtextures in spinel and plagioclase peridotites. a Spinel peridotite MM1/9. Not exolved orthopyroxene $(O P X s)+$ spinel symplectitic intergrowths crystallized at the rims of large exolved orthopyroxene porphyroclast (OPXp) (plane-polarized light). b Photograph (a) at cross-polarized light. Olivine embayments $(O L)$ partly corroding the opx porphyroclast and the (opx $+\mathrm{sp})$ symplectite. c Spinel peridotite MM2/11. Exolved clinopyroxene porphyroclast $(C P X p)$ partly replaced by olivine (cross-polarized light). d Spinel peridotite MM2/12. Exolved orthopyroxene porphyroclast $(O P X p)$ partly replaced by olivine, thus showing extremely irregular outlines

characterized by strong LREE depletion (Fig. 6). Less marked LREE fractionation is shown by clinopyroxenes in sample MM2/11. Within a single sample, clinopyroxenes record a systematic decrease in $\mathrm{Al}$ and $\mathrm{Cr}$ contents, coupled to $\mathrm{Mg}$-value increase, from porphyroclast cores to porphyroclast rims and small grains in the symplectitic aggregates (Fig. 6a); by contrast, no significant withingrain trace element zoning is observed. In the plagioclase peridotites, clinopyroxenes display within-sample large compositional variations related to microstructure. The cores of clinopyroxene porphyroclasts still preserve high $\mathrm{Al}$ and low Ti concentrations, whereas $\mathrm{Al}, \mathrm{Sr}$ decrease coupled (cross-polarized light). e Plagioclase peridotite MM1/10. Large unstrained poikilitic orthopyroxene $(O P X p k)$ partly replacing kinked mantle olivine. The poikilitic orthopyroxene constitutes a single crystal in continuity with the orthopyroxene rim crystallized around clinopyroxene porphyroclast $(C P X P R)$ (cross-polarized light). f Plagioclase peridotite MM1/11. (Opx + plag) intergrowths partially replacing exolved and deformed mantle clinopyroxene $(C P X p R)$. The orthopyroxene continues in a large poikilitic grain $(O P X p k)$ substituting olivine (cross-polarized light)

to Ti, Sc, V, Zr, Y, REE increase is observed at the rims of "reacted" clinopyroxenes (replaced by opx + plag intergrowths) (Figs. 6b, 7a, 8; Tables 3, 4), although they preserve similar LREE depletion. Orthopyroxenes in the spinel peridotites display major element variations consistent with those observed in clinopyroxenes, i.e. decrease in $\mathrm{Al}, \mathrm{Cr}, \mathrm{Ca}$ contents, coupled to slight $\mathrm{Mg}$-value increase, from porphyroclast cores to rims and small grains in the symplectitic aggregates (Supplementary Table 3). No remarkable major element chemical differences are observed in orthopyroxenes from sample MM2/11, except for higher $\mathrm{CaO}$ contents (up to $2.3 \mathrm{wt} \%$ ) still recorded in 
Table 2 Trace element bulk-rock compositions of the Mt.Maggiore peridotites and gabbronoritic veinlets

\begin{tabular}{|c|c|c|c|c|c|c|c|c|c|}
\hline & \multicolumn{5}{|c|}{ Spinel peridotites } & \multicolumn{3}{|c|}{ Plagioclase peridotites } & \multirow{2}{*}{$\begin{array}{l}\text { Veinle } \\
\text { M14 }\end{array}$} \\
\hline & MM1/5 & MM1/9 & MM2/12 & MM2/10 & MM2/11 & MM1/11 & MM1/10 & $\mathrm{MM} 2 / 5 \mathrm{~A}$ & \\
\hline $\mathrm{Rb}$ & 0.084 & 0.083 & 0.085 & 0.12 & 0.074 & 0.092 & 0.077 & 0.11 & 0.062 \\
\hline $\mathrm{Sr}$ & 0.19 & 0.13 & 0.19 & 0.14 & 0.25 & 0.51 & 0.37 & 3.69 & 28 \\
\hline $\mathrm{Y}$ & 1.18 & 1.56 & 1.1 & 1.34 & 0.62 & 1.7 & 1.98 & 1.89 & 1.615 \\
\hline $\mathrm{Zr}$ & 0.33 & 0.26 & 0.16 & 0.22 & 0.25 & 0.31 & 0.41 & 0.49 & 0.736 \\
\hline $\mathrm{Nb}$ & 0.026 & 0.025 & 0.028 & 0.046 & 0.028 & 0.024 & 0.022 & 0.025 & 0.035 \\
\hline $\mathrm{Ce}$ & 0.013 & 0.008 & 0.009 & 0.015 & 0.012 & 0.01 & 0.016 & 0.022 & 0.073 \\
\hline $\operatorname{Pr}$ & 0.0065 & 0.0045 & 0.0035 & 0.011 & 0.004 & 0.007 & 0.008 & 0.011 & 0.028 \\
\hline $\mathrm{Nd}$ & 0.057 & 0.053 & 0.035 & 0.075 & 0.039 & 0.07 & 0.092 & 0.097 & 0.235 \\
\hline $\mathrm{Sm}$ & 0.047 & 0.056 & 0.037 & 0.05 & 0.029 & 0.063 & 0.08 & 0.075 & 0.139 \\
\hline $\mathrm{Eu}$ & 0.021 & 0.025 & 0.016 & 0.022 & 0.012 & 0.028 & 0.035 & 0.042 & 0.15 \\
\hline Gd & 0.1 & 0.13 & 0.085 & 0.12 & 0.058 & 0.15 & 0.18 & 0.18 & 0.221 \\
\hline $\mathrm{Tb}$ & 0.022 & 0.03 & 0.02 & 0.026 & 0.012 & 0.033 & 0.039 & 0.038 & 0.049 \\
\hline Dy & 0.18 & 0.24 & 0.16 & 0.21 & 0.095 & 0.26 & 0.3 & 0.3 & 0.305 \\
\hline Ho & 0.045 & 0.058 & 0.041 & 0.051 & 0.023 & 0.062 & 0.072 & 0.071 & 0.076 \\
\hline Er & 0.14 & 0.18 & 0.13 & 0.163 & 0.075 & 0.2 & 0.22 & 0.22 & 0.215 \\
\hline $\mathrm{Tm}$ & 0.023 & 0.029 & 0.022 & 0.027 & 0.013 & 0.031 & 0.035 & 0.035 & 0.031 \\
\hline $\mathrm{Yb}$ & 0.15 & 0.2 & 0.15 & 0.18 & 0.092 & 0.21 & 0.23 & 0.23 & 0.189 \\
\hline $\mathrm{Lu}$ & 0.028 & 0.037 & 0.028 & 0.032 & 0.018 & 0.037 & 0.04 & 0.041 & 0.03 \\
\hline $\mathrm{Hf}$ & 0.028 & 0.03 & 0.022 & 0.029 & 0.02 & 0.038 & 0.045 & 0.042 & 0.057 \\
\hline Ta & 0.0012 & 0.0013 & 0.0013 & 0.0025 & 0.0021 & 0.0015 & 0.001 & 0.001 & 0.01 \\
\hline $\mathrm{Ce}_{\mathrm{N}} / \mathrm{Yb}_{\mathrm{N}}$ & 0.022 & 0.010 & 0.015 & 0.022 & 0.034 & 0.012 & 0.018 & 0.025 & 0.104 \\
\hline
\end{tabular}

Trace element contents are given in ppm

some porphyroclast cores. In the plagioclase peridotites, the most evident chemical change in orthopyroxene is the $\mathrm{Al}$ decrease and $\mathrm{Ca}$ increase, from porphyroclasts to reaction rims around cpx and poikilitic grains substituting mantle olivine (Supplementary Table 3). Opx porphyroclasts and poikilitic grains have similar trace element contents, whereas higher REE, $\mathrm{Ti}, \mathrm{Zr}$ concentrations, coupled to $\mathrm{Eu}$ negative anomalies, are shown by the opx reaction rims around cpx (Table 5, Fig. 7a). Spinels in the spinel peridotites define narrow compositional ranges (Fig. 9a). Within a single sample, slight $\mathrm{Mg}$-number increase is observed in spinels from symplectitic aggregates, relative to larger grains (Supplementary Table 4 ). $\mathrm{TiO}_{2}$ contents vary from 0.12 to $0.26 \mathrm{wt} \%$, with the highest values in spinel from sample MM2/11. In the plagioclase peridotites, spinels exhibit higher Cr-numbers, related to equilibration with plagioclase, coupled to higher $\mathrm{TiO}_{2}$ abundances (0.44$0.60 \mathrm{wt} \%$ ), as commonly observed in spinels from plagioclase-bearing abyssal peridotites (Hellebrand et al. 2002). Plagioclase in the peridotites is mostly replaced by lowgrade alteration products. Unaltered plagioclase only occurs in sample MM2/5A. It shows high An values (87-89\%), LREE depleted patterns and low $\mathrm{Sr}$ contents $(\mathrm{Sr}=18.5-$ $28.7 \mathrm{ppm}$ ), consistent with previously published data (Rampone et al. 1997) (Supplementary Table 5, Table 4).
Mineral compositions in the gabbronoritic veinlets are similar to those in the peridotites. Olivine, clinopyroxene and orthopyroxene have high Mg-numbers (0.89-0.90) (Supplementary Tables 1, 2, 3). Clinopyroxenes are LREE depleted (Fig. 7b), and display core-rim major and trace element chemical zoning similar to that observed in the plagioclase peridotites, i.e. REE, Ti, Zr, Y increase, and development of Eu negative anomalies from cores to rims of larger grains, to tiny rims interstitial between plagioclase crystals (Figs. 7b, 8) (Table 6). Orthopyroxene cores preserve high Ca contents (up to $2.75 \mathrm{wt} \%$ ) indicative of their magmatic high- $T$ equilibration. Their trace element compositions are similar to those of poikilitic opx in the impregnated peridotites (Fig. 7b). Plagioclase also bears a depleted trace element composition, marked by high An contents (84-88\%), LREE depletion (Fig. 7b), and very low $\mathrm{Sr}$ (22.9-30.5 ppm) abundances.

\section{Geothermometric estimates}

Equilibration temperatures for the different recrystallization stages recorded by the spinel and plagioclase peridotites were obtained applying different geothermometric methods (Wells 1977; Taylor 1998; Brey and 

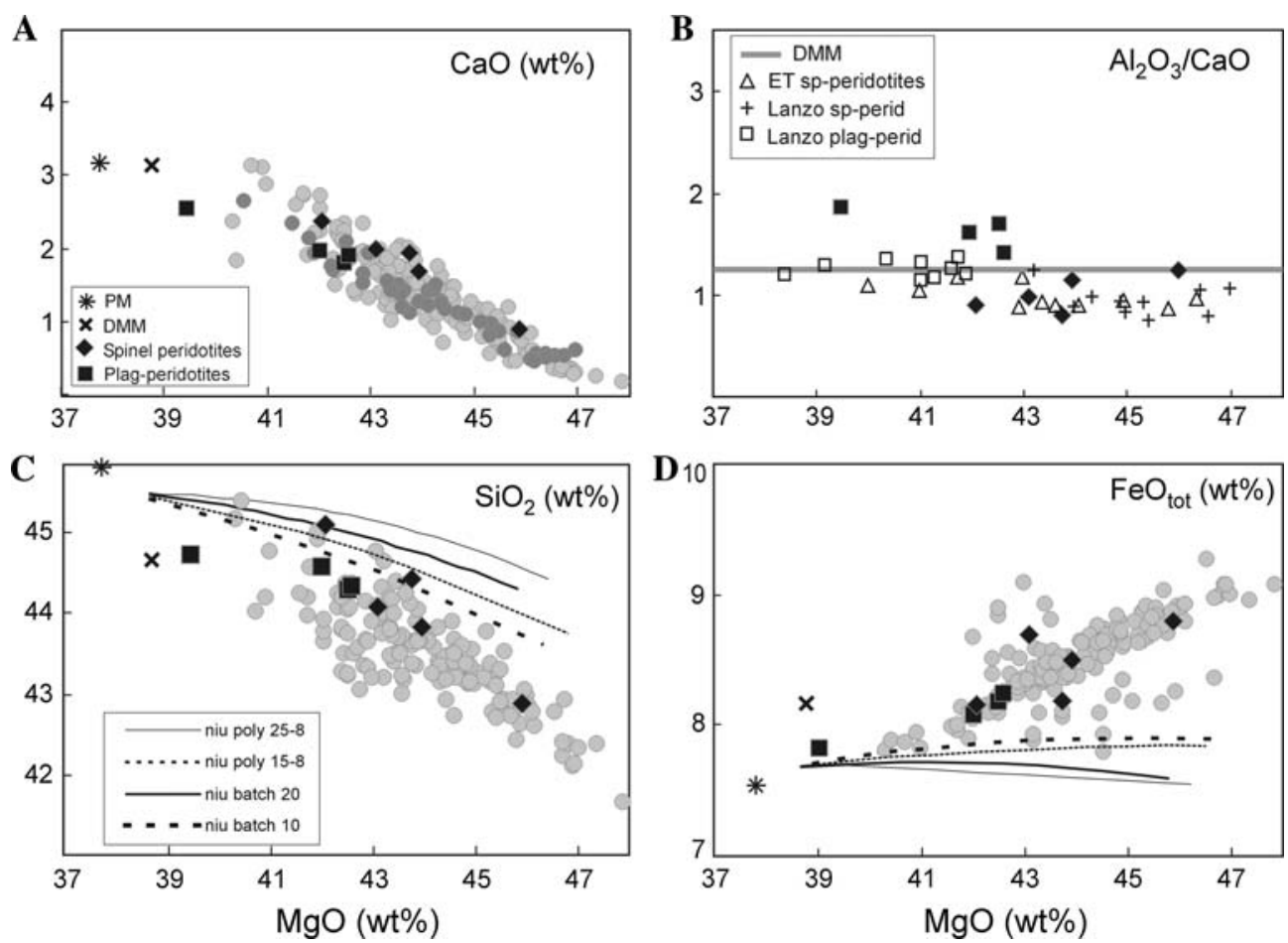

Fig. 4 Bulk rock abundances of $\mathrm{MgO}$ vs. $\mathrm{CaO}, \mathrm{Al}_{2} \mathrm{O}_{3} / \mathrm{CaO}, \mathrm{SiO}_{2}$ and $\mathrm{FeO}_{\text {tot }}$ (data on anhydrous basis in $\mathrm{wt} \%$ ), in the Mt.Maggiore spinel and plagioclase peridotites. Primordial mantle $(P M)$ and depleted MORB mantle (DMM) estimates from Hofmann (1988) and Workman and Hart (2005), respectively. Also reported are: (1) estimated

compositions of abyssal peridotites from Niu et al. 1997 (light grey dots) and Baker and Beckett 1999 (dark grey dots) and (2) fractional (polybaric) and batch melting trends (adapted from Niu et al. 1997). Data for spinel and plagioclase-bearing impregnated peridotites of the Lanzo massif (reported in Fig. 4b) are from Piccardo et al. 2007

Kohler 1990; Seitz et al. 1999). In general, geothermometers based on opx-cpx major element exchange yield significantly lower temperatures relative to the $\mathrm{Ca}$ in opx method of Brey and Kohler (1990), and the Seitz et al. (1999) geothermometer based on trace element (Sc, V) opx-cpx partitioning. This could be due to the fact that clinopyroxene porphyroclasts are generally more exsolved than coexisting orthopyroxene, and their major element compositions rarely preserve the high- $T$ equilibration. Higher $T$ estimates obtained using the clinopyroxene trace element compositions could be consequence of the larger $(80-100 \mu)$ LA-IPC-MS spot used for trace element analyses, which thus better approach exsolution-integrated compositions. We have thus considered only the results of Brey and Kohler (1990) Ca in opx, and Seitz et al. (1999) methods; for the latter we have used the Sc and V geothermometers and eliminated the $T$ estimates differing by more than $50^{\circ} \mathrm{C}$. A summary of $T$ estimates for the different stages is reported in Supplementary Table 6.

In the spinel peridotites the oldest spinel-facies equilibration, determined using the composition of pyroxene porphyroclast cores, yields temperatures mostly between 1,100 and $1,150^{\circ} \mathrm{C}$. Slightly lower temperatures (970$1,100^{\circ} \mathrm{C}$ ) were obtained for the symplectitic spinel-facies recrystallization. In a few samples (MM2/11, MM2/12),

the pyroxene porphyroclasts record higher equilibration $T$, ranging $1,200-1,300^{\circ} \mathrm{C}$. In the plagioclase peridotites, spinel-facies pyroxene porphyroclasts furnish temperatures in the interval $1,050-1,150^{\circ} \mathrm{C}$, similar to most spinel peridotites. Higher $T$ estimates (mostly varying 1,150$1,250^{\circ} \mathrm{C}$ ) were obtained using the compositions of reacted clinopyroxene porphyroclast rims and opx reaction rims, representative of the impregnation stage.

\section{Discussion}

Spinel peridotites: melt-rock interaction by reactive porous flow

Spinel peridotites have a depleted chemical signature, similar to many abyssal peridotites, thus indicating that they likely experienced MORB-type partial melting. However, as documented in other depleted peridotites (Niu 1997; Godard et al. 2000; Rampone et al. 2004; Piccardo et al. 2007; Seyler et al. 2007), textural and bulk/mineral chemical features suggest that some of the peridotites are not consistent with simple melting residues, rather their compositions were variably modified by melt-rock interaction. 


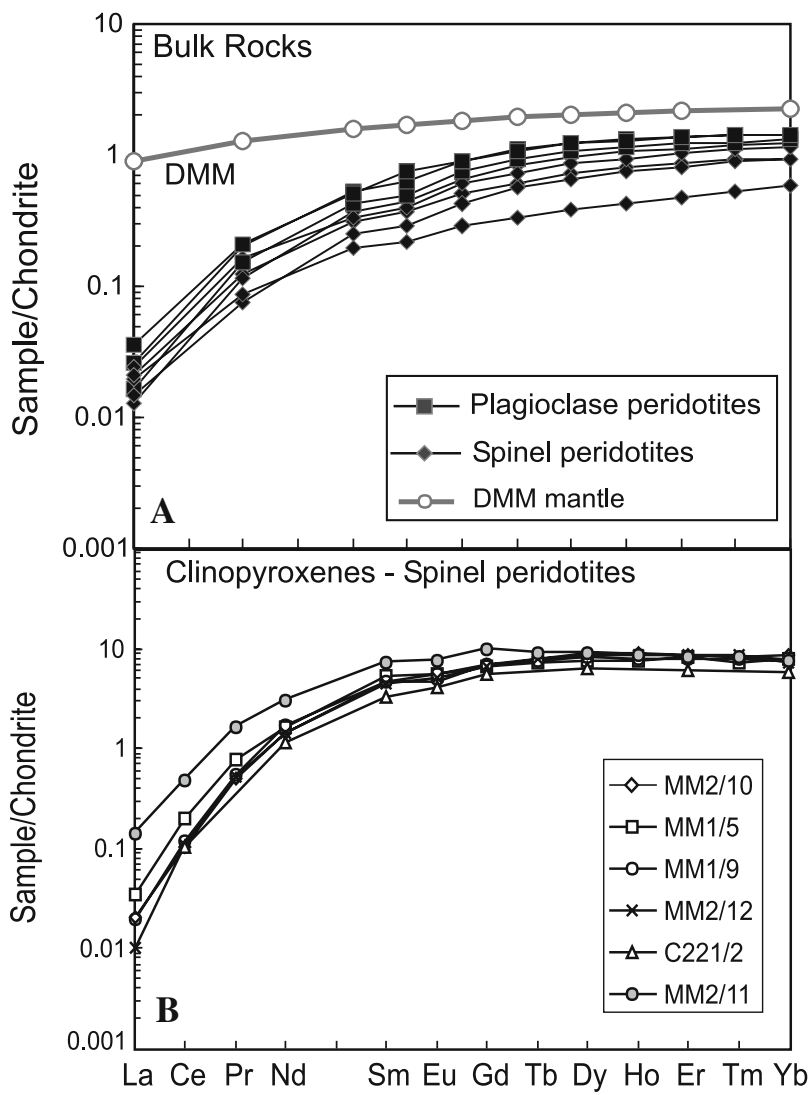

Fig. 5 a Bulk rock REE abundances (normalized to Chondrite C1 after Anders and Ebihara 1982) of the Mt.Maggiore spinel and plagioclase peridotites. Also reported is the estimated REE bulk composition of the depleted MORB mantle (DMM, adapted from Workman and Hart 2005). b Chondrite-normalized REE abundances of clinopyroxenes in the spinel peridotites. Clinopyroxene compositions within a single sample are quite homogeneous, and the reported REE spectra represent the average composition of at least three different analyses

\section{Microtextural evidence}

In the spinel peridotites, the oldest equilibration stage is represented by a coarse-grained porphyroclastic spinelbearing mineral assemblage showing evidence of a weak internal plastic deformation. As discussed by Dijkstra et al. (2003) for the Othris peridotites, the coarse-grained crystallization could represent a high- $T$ equilibration stage occurred at asthenospheric conditions or in the TBL, i.e. at depth where the peridotites, after melting, progressively cool and become incorporated in the thermal lithosphere. However, application of geothermometric methods to the primary spinel-facies assemblage furnished relatively low equilibration $T\left(1,100-1,150^{\circ} \mathrm{C}\right)$, as expected from the diffuse occurrence of exsolutions within pyroxene porphyroclasts, indicating cooling of the peridotites at lithospheric environments. Spinel peridotites also show the diffuse occurrence of opx $+\operatorname{spinel}( \pm \mathrm{cpx})$ symplectites at
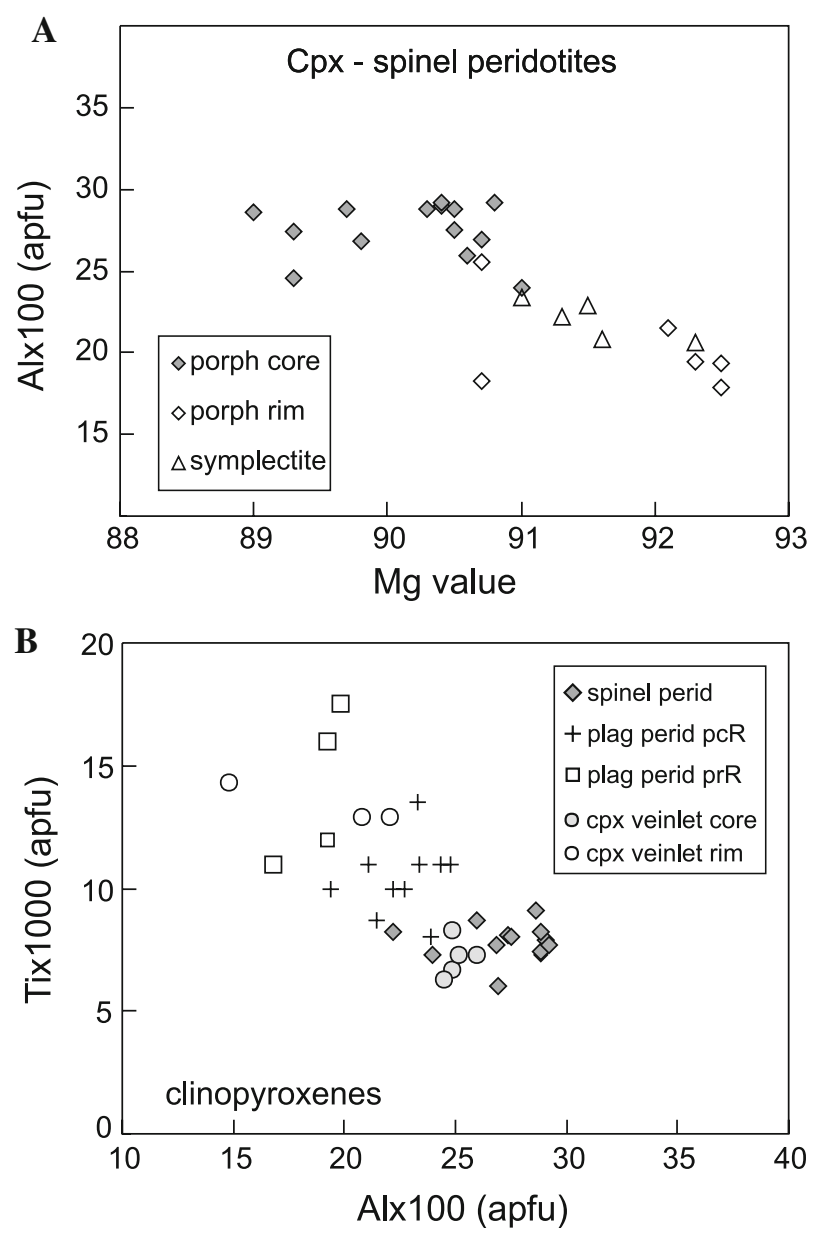

Fig. 6 Variation of a $\mathrm{Mg}$ value vs. $\mathrm{Al}(\times 100)$ and $\mathbf{b} \mathrm{Al}(\times 100)$ vs. $\mathrm{Ti}$ $(\times 1,000)$ (atoms per six oxygens) for clinopyroxenes in the Mt.Maggiore peridotites. In a we reported the clinopyroxene compositions in the spinel peridotites. Porph core and porph rim refers to cores and rims of clinopyroxene porphyroclasts; symplectite refers to clinopyroxenes in the symplectitic aggregates. In $\mathbf{b}$ we compare the compositions of clinopyroxene porphyroclast cores in the spinel peridotites (spinel perid) with those of clinopyroxenes in the plagioclase peridotites (plag perid) and in the plag-rich veinlets; $\mathrm{pcR}=$ core of reacted porphyroclast, $\mathrm{prR}=\mathrm{rim}$ of reacted porphyroclast

the rims of large orthopyroxene porphyroclasts. Chemical changes in symplectitic minerals (e.g. Al, Cr decrease and Mg-number increase in pyroxenes) (see Fig. 6a) are consistent with the decreased solubility of the $\mathrm{Cr}-\mathrm{Al}$ component (CrMgTs) in pyroxenes (Nagata et al. 1983; Klemme and O'Neil 2000), and subsolidus $\mathrm{Fe}-\mathrm{Mg}$ exchange reactions between pyroxenes and spinel at decreasing temperature. This is confirmed by the equilibration $T$ obtained on the symplectitic stage (970$\left.1,100^{\circ} \mathrm{C}\right)$. Similar "cooling textures" were documented in the Erro-Tobbio, Lanzo South and Othris spinel peridotites (Piccardo et al. 2007; Piccardo and Vissers 2007; Barth et al. 2003), and were related to their incorporation to the thermal lithosphere. Textural features and geothermometry 


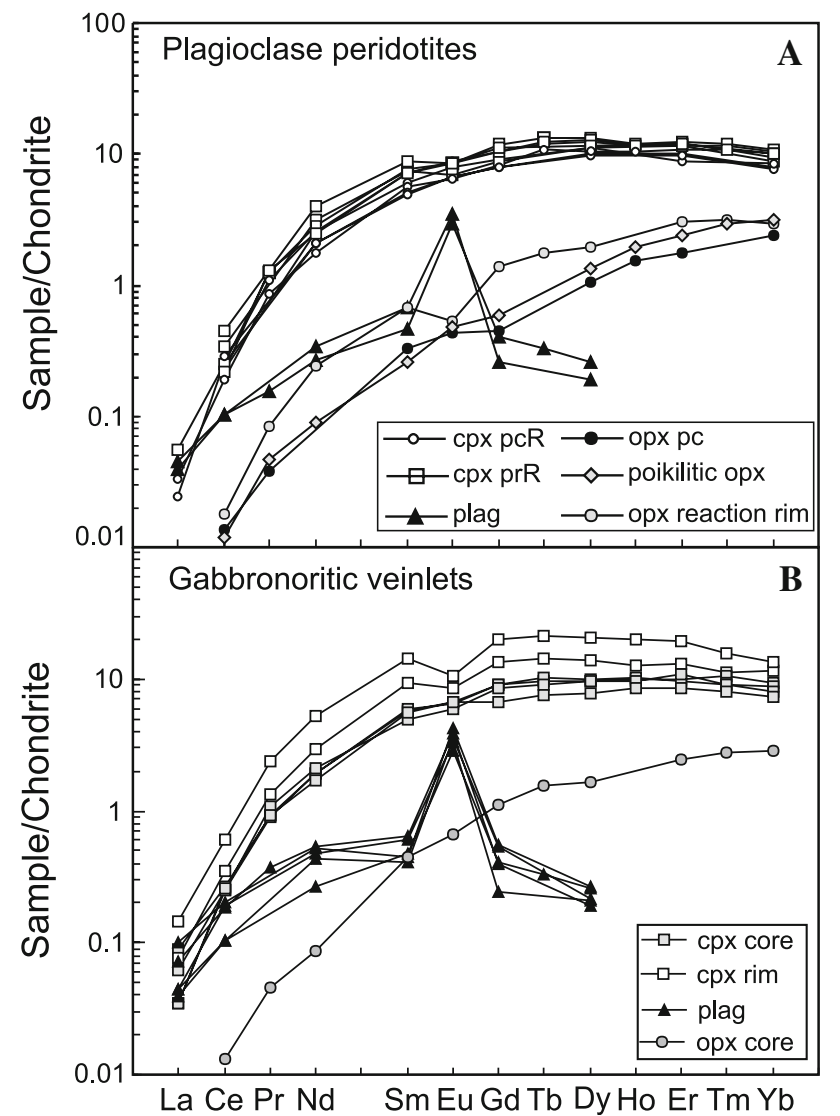

Fig. 7 Chondrite-normalized REE abundances of clinopyroxene, orthopyroxene and plagioclase in the plagioclase peridotites (a) and in the gabbronoritic veinlets (b). Abbreviations as in Fig. 6. In a, poikilitic opx refers to grains substituting mantle olivine, and opx reaction rim are orthopyroxene grains crystallized as reaction rims (together with plagioclase) at the expense of mantle clinopyroxene. Normalization factors as in Fig. 5

in the Mt.Maggiore peridotites thus indicate that the spinel peridotites, presumably after a melting event, were accreted and cooled at lithospheric depths. Similar microstructures, i.e. $(\mathrm{px}+$ spinel) symplectites at the rims of orthopyroxene porphyroclasts, were also documented in MAR harzburgites (Seyler et al. 2007); in this case however, no systematic correlations between $\mathrm{Mg \#}$ and $\mathrm{Cr}, \mathrm{Al}$ contents are recorded in pyroxenes, and the authors inferred that the symplectitic aggregates resulted from infiltration of melt that reacted with the opx and precipitated spinel \pm cpx.

Spinel peridotites display melt-rock reaction microstructures mostly evidenced by the development of large embayments of olivine within exsolved pyroxene porphyroclasts, which often show extremely irregular outlines (see Fig. 3c, d). Replacement of orthopyroxene by olivine can be ascribed to the incongruent melting reaction opx $\Rightarrow$ ol + melt characteristic of decompression melting beneath ocean ridges, as inferred in abyssal peridotites by
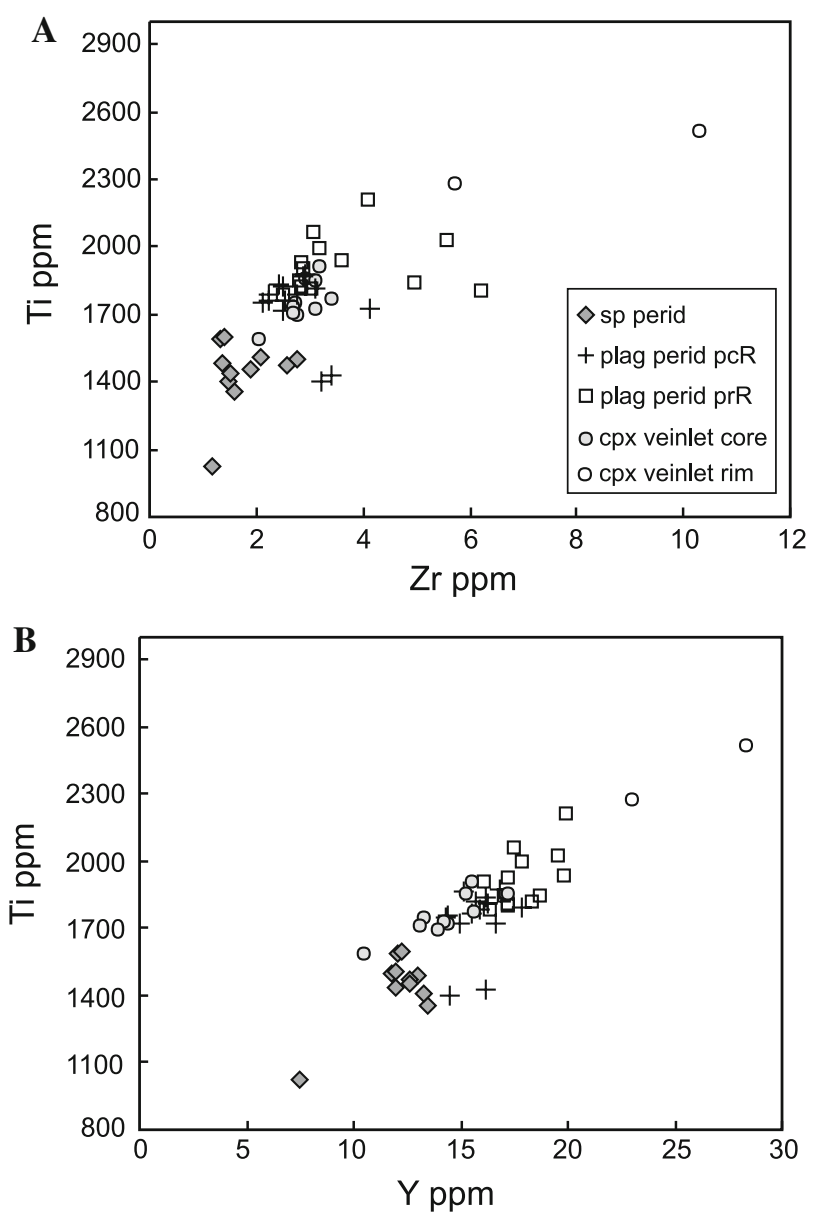

Fig. 8 Variation of a $\mathrm{Zr}(\mathrm{ppm})$ vs. Ti (ppm) and b Y (ppm) vs. Ti (ppm) in clinopyroxenes from spinel peridotites, plagioclase peridotites and gabbronoritic veinlets. Symbols and abbreviations as in Fig. 6

Niu (1997). According to this interpretation, the observed melt-rock reaction textures would represent a melting feature. On the other hand, the dissolution of orthopyroxene and replacement by olivine can be enhanced by the reaction between hot ascending melts and surrounding residual peridotites. Melt rising adiabatically is above its liquidus temperatures and saturated in olivine: it will thus crystallize olivine and continue to dissolve pyroxenes in the host peridotites, according to a process of reactive porous flow. Similar textures were documented in the Othris, South Lanzo and Erro-Tobbio spinel peridotites, and interpreted as reflecting either a melting feature (Barth et al. 2003) or open-system porous flow migration and interaction of peridotites with pyroxene undersaturated melts (Dijkstra et al. 2003; Piccardo et al. 2007; Piccardo and Vissers 2007). Orthopyroxene resorption and replacement by olivine was also reported in MAR abyssal peridotites, and interpreted as resulting from a reactive porous flow process (Seyler et al. 2007). 
Table 3 Trace element compositions of clinopyroxenes in spinel peridotites

\begin{tabular}{|c|c|c|c|c|c|c|c|c|c|c|c|}
\hline & \multicolumn{11}{|c|}{ Porphyroclast core } \\
\hline & $\mathrm{MM} 2 / 10$ & MM2/10 & MM1/5 & MM1/9 & MM1/9 & MM2/12 & MM2/12 & $\mathrm{C} 221 / 2^{\mathrm{a}}$ & $\mathrm{C} 221 / 2^{\mathrm{a}}$ & MM2/11 & MM2/11 \\
\hline $\mathrm{Sc}$ & 58 & 57 & 56 & 52 & 53 & 54 & 55 & 48 & 40 & 58 & 57 \\
\hline $\mathrm{Ti}$ & 1,486 & 1,355 & 1,502 & 1,453 & 1,435 & 1,591 & 1,600 & 1,510 & 1,028 & 1,540 & 1,470 \\
\hline V & 310 & 261 & 294 & 290 & 310 & 300 & 312 & 245 & 222 & 261 & 266 \\
\hline $\mathrm{Sr}$ & 1.00 & 0.85 & 2.07 & 1.05 & 0.72 & 1.02 & 0.59 & 1.10 & 0.56 & 1.71 & 1.89 \\
\hline Y & 13.0 & 13.5 & 11.7 & 12.6 & 12.0 & 12.1 & 12.2 & 12.0 & 7.50 & 14.2 & 12.6 \\
\hline $\mathrm{Zr}$ & 1.35 & 1.60 & 2.78 & 1.89 & 1.50 & 1.34 & 1.41 & 2.10 & 1.17 & 4.29 & 3.09 \\
\hline $\mathrm{La}$ & 0.0039 & 0.0054 & 0.0080 & 0.0051 & 0.0040 & 0.0021 & 0.0026 & - & - & 0.0237 & 0.0328 \\
\hline $\mathrm{Ce}$ & 0.07 & 0.05 & 0.12 & 0.08 & 0.07 & 0.08 & 0.05 & 0.08 & 0.05 & 0.30 & 0.25 \\
\hline $\operatorname{Pr}$ & 0.04 & 0.04 & 0.07 & 0.05 & 0.05 & 0.05 & 0.04 & - & - & 0.15 & 0.14 \\
\hline $\mathrm{Nd}$ & 0.65 & 0.67 & 0.75 & 0.83 & 0.69 & 0.69 & 0.61 & 0.76 & 0.26 & 1.32 & 1.30 \\
\hline $\mathrm{Sm}$ & 0.65 & 0.72 & 0.79 & 0.81 & 0.59 & 0.62 & 0.68 & 0.58 & 0.38 & 1.24 & 0.90 \\
\hline $\mathrm{Eu}$ & 0.25 & 0.25 & 0.32 & 0.34 & 0.27 & 0.28 & 0.29 & 0.28 & 0.18 & 0.45 & 0.38 \\
\hline $\mathrm{Gd}$ & 1.25 & 1.33 & 1.32 & 1.53 & 1.21 & 1.35 & 1.29 & 1.27 & 0.9 & 2.33 & 1.60 \\
\hline $\mathrm{Tb}$ & 0.29 & 0.31 & 0.27 & 0.30 & 0.26 & 0.28 & 0.29 & - & - & 0.37 & 0.30 \\
\hline Dy & 2.14 & 2.22 & 1.85 & 2.08 & 1.94 & 2.05 & 2.13 & 1.89 & 1.19 & 2.46 & 2.07 \\
\hline Но & 0.50 & 0.46 & 0.41 & 0.47 & 0.41 & 0.45 & 0.50 & - & - & 0.57 & 0.44 \\
\hline $\mathrm{Er}$ & 1.39 & 1.41 & 1.31 & 1.29 & 1.23 & 1.32 & 1.44 & 0.99 & 0.72 & 1.40 & 1.30 \\
\hline $\mathrm{Tm}$ & 0.19 & 0.23 & 0.18 & 0.20 & 0.18 & 0.21 & 0.21 & - & - & 0.24 & 0.17 \\
\hline $\mathrm{Yb}$ & 1.48 & 1.34 & 1.26 & 1.22 & 1.28 & 1.18 & 1.22 & 1.1 & 0.78 & 1.36 & 1.21 \\
\hline $\mathrm{Lu}$ & 0.18 & 0.22 & 0.16 & 0.17 & 0.18 & 0.17 & 0.19 & - & - & 0.19 & 0.16 \\
\hline Hf & 0.23 & 0.22 & 0.27 & 0.20 & 0.15 & 0.24 & 0.21 & - & - & 0.29 & 0.30 \\
\hline $\mathrm{Ce}_{\mathrm{N}} / \mathrm{Yb}_{\mathrm{N}}$ & 0.012 & 0.010 & 0.026 & 0.017 & 0.014 & 0.018 & 0.012 & 0.018 & 0.012 & 0.059 & 0.056 \\
\hline
\end{tabular}

Trace element contents are given in ppm

a Analyses performed by SIMS technique. All other analyses by LA-ICP-MS

In the Mt.Maggiore peridotites, olivine replacement also occurs at the expense of the symplectitic textures (Fig. 3b), thus indicating that the low- $T$ recrystallization likely preceded the reaction events. This is confirmed by the evidence that symplectites are better preserved in samples MM1/9, MM2/10 and MM1/5, which show less diffuse melt-rock reaction microstructures. By contrast, the most evident pyroxene dissolution and olivine replacement reactions are observed in samples MM2/12 and MM2/11, which also record high equilibration $T\left(1,200-1,300^{\circ} \mathrm{C}\right)$, and in which opx + sp recrystallized aggregates are rarely found. Textural features in the spinel peridotites thus suggest that the melt-rock reaction stage does not represent a melting feature. Rather, it reflects melt-rock interaction subsequent to the melting event. In the following, we will show that chemical characteristics of spinel peridotites also support this interpretation.

\section{Inferences from mineral chemistry data}

Mineral compositions in the studied spinel peridotites are rather homogeneous and generally depleted. In Fig. 9a, the REE abundances of clinopyroxenes are compared with computed REE compositions of residual clinopyroxenes after increasing degrees of fractional melting in the spinelfacies stability field. Overall, they are consistent with residua after low-degrees $(F=5-8 \%)$ of fractional melting. In terms of cpx REE chemistry, the least depleted compositions are shown by clinopyroxenes from sample MM2/11 (see Fig. 5b). If we also consider the spinel chemistry, and use the Hellebrand et al. (2001) equation to calculate the degree of melting recorded by spinel peridotites, we obtain fractional melting degrees in the range $7-11 \%$, slightly higher than those inferred from clinopyroxenes. The lack of a good correlation between spinel and clinopyroxene chemistry is evident in Fig. 9b, which shows the Cr-number in spinel vs. $\mathrm{Yb}_{\mathrm{N}}$ in clinopyroxene for both spinel and plagioclase peridotites, together with the melting trend defined by abyssal peridotites (Hellebrand et al. 2001). Spinel peridotites lie roughly on the melting trend, whereas plagioclase peridotites display higher $\mathrm{Cr}$-number in spinel, because the equilibration with plagioclase modifies the spinel chemistry towards $\mathrm{Cr}$ richer and $\mathrm{Al}$ poorer compositions. Within the spinel peridotites, the best fit between clinopyroxene and spinel compositions, in terms of estimate of the depletion degree, is shown by samples 


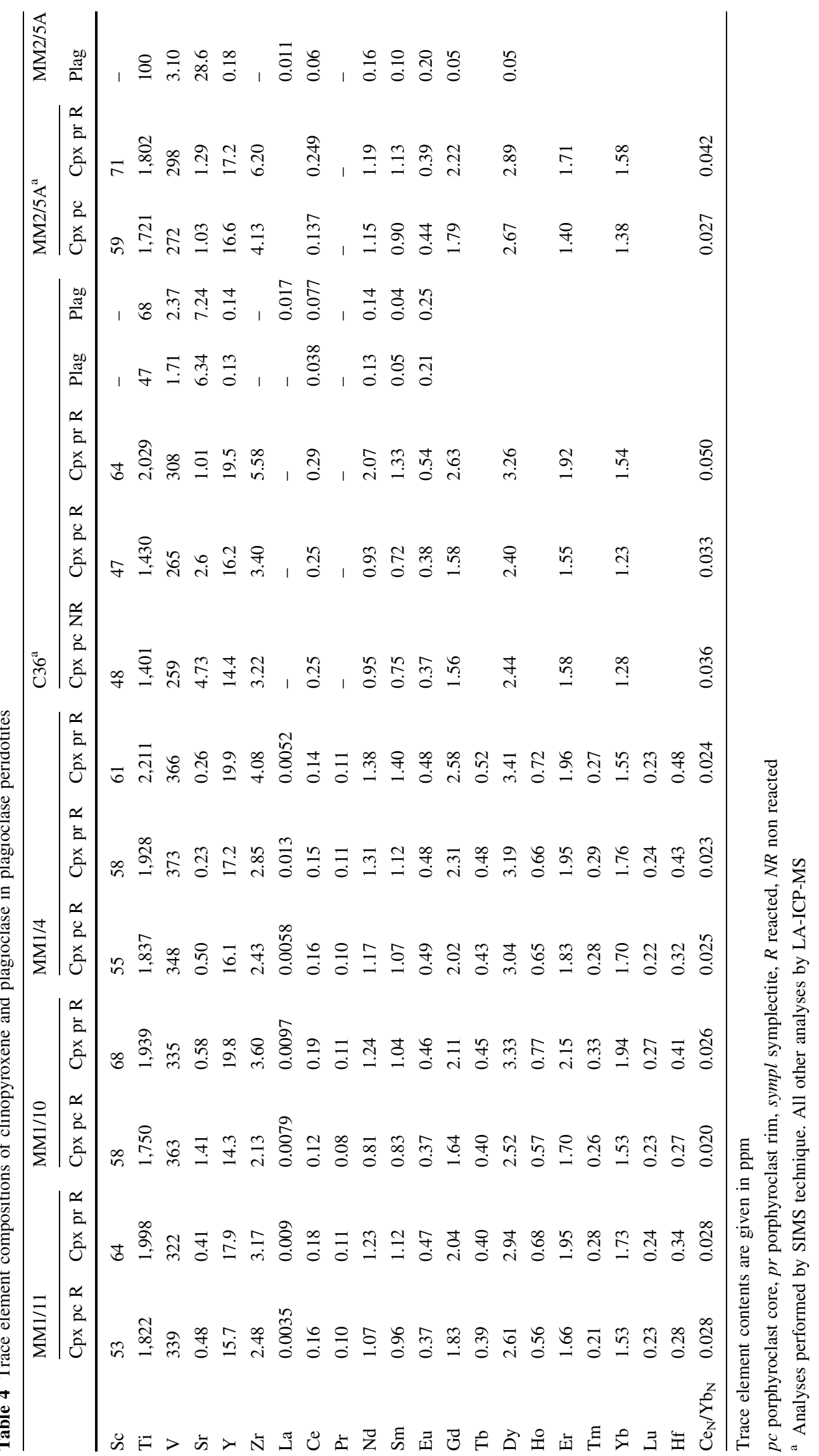




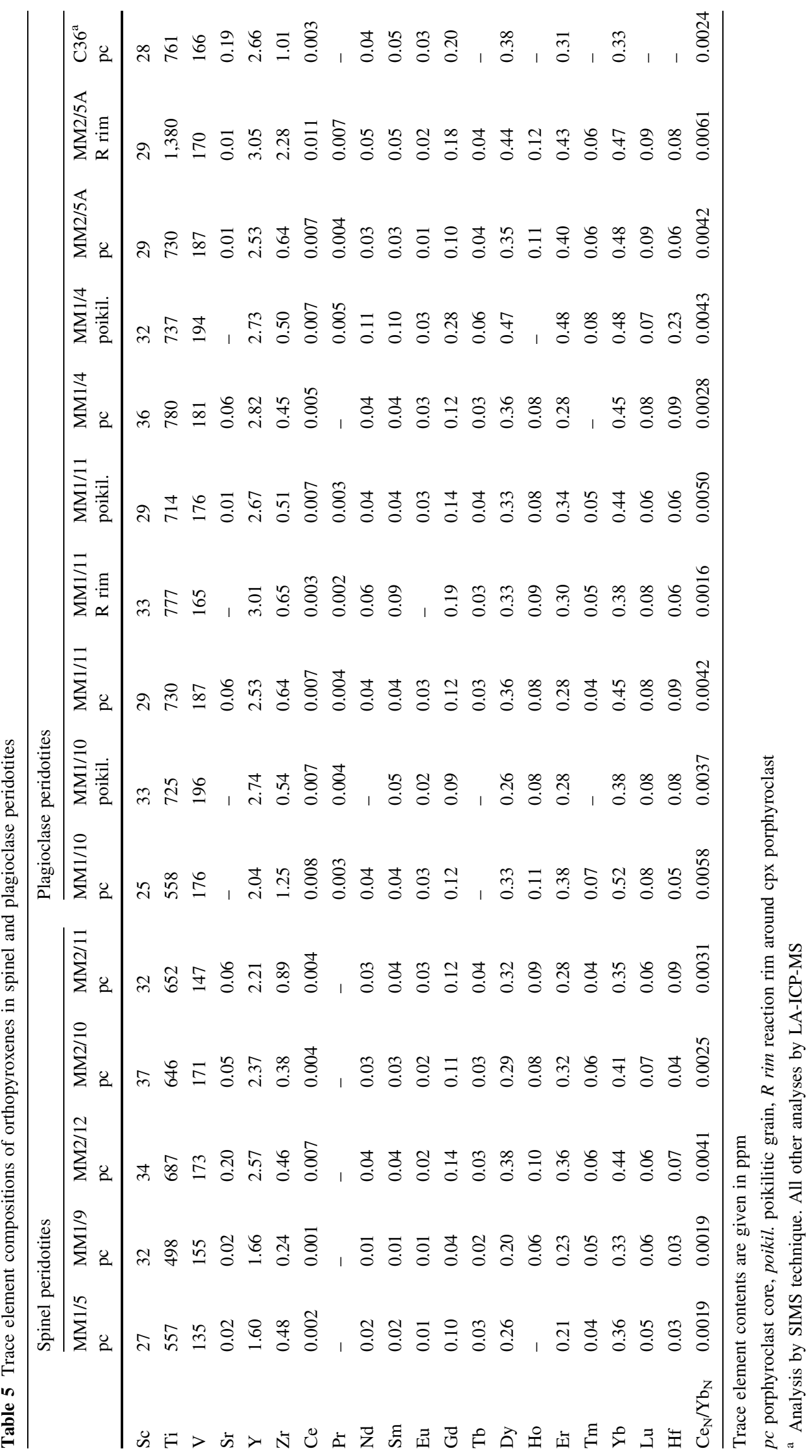



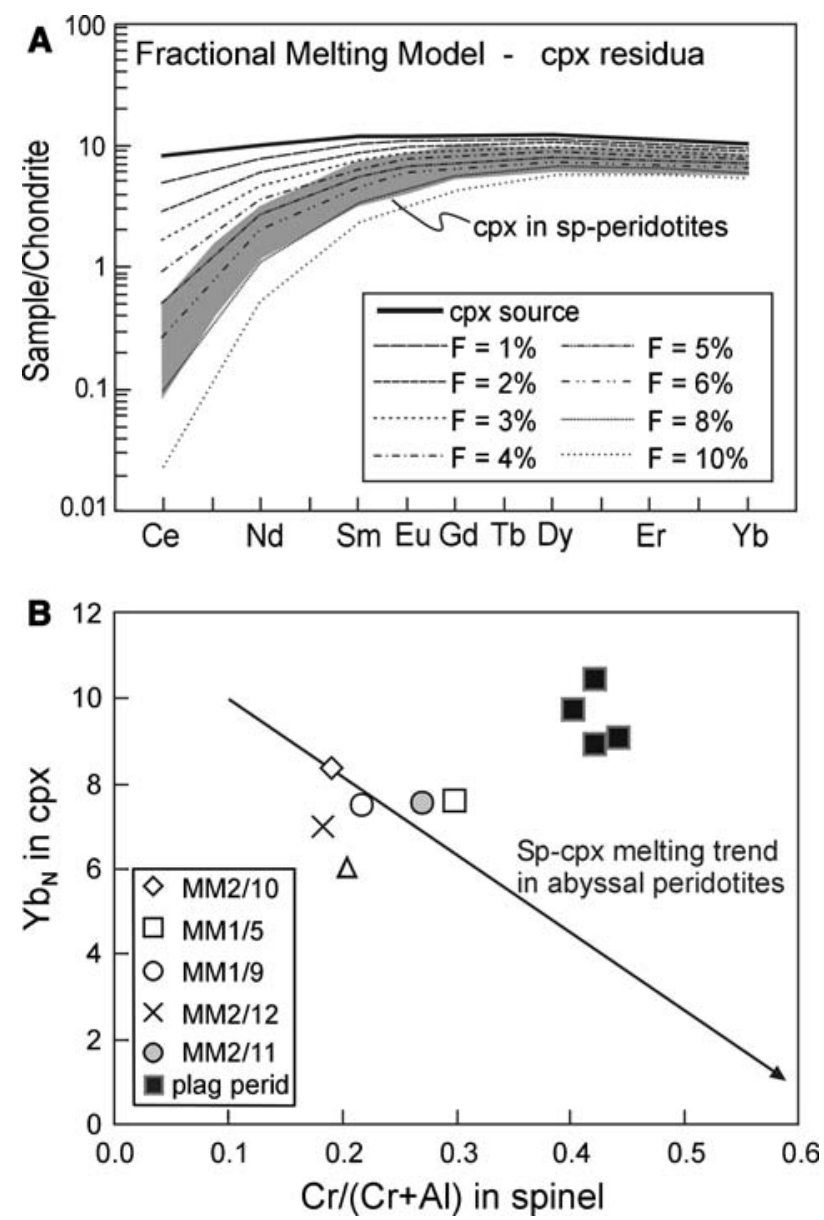

Fig. 9 a Chondrite-normalized REE spectra of residual clinopyroxenes after variable degrees $(F)$ of fractional melting. Source composition and equations are from Johnson et al. (1990), peridotite and melt modes from Kinzler (1997) and distribution coefficients from Suhr et al. (1998). Also reported is the compositional field (in grey) defined by clinopyroxenes in the spinel peridotites. b $\mathrm{Cr} /$ $(\mathrm{Cr}+\mathrm{Al})$ in spinel vs. $\mathrm{Yb}_{\mathrm{N}}$ in clinopyroxene for the Mt.Maggiore spinel and plagioclase peridotites. Also reported is the mantle melting trend, as defined by Hellebrand et al. (2001) based on spinel and clinopyroxene compositions in abyssal peridotites

MM2/10 and MM1/9. Mineral compositions in the spinel peridotites are thus indicative of mantle residua after variable $(<10 \%)$ fractional melting degrees. It is remarkable, however, that the least depleted REE cpx compositions are recorded in the spinel harzburgite MM2/11 (Fig. 5b), which shows the most depleted bulk rock abundances (Figs. 4, 5a). The MM spinel peridotites thus exhibit contrasting bulk vs. mineral chemical features which cannot be simply reconciled with partial melting.

\section{Bulk vs. mineral chemistry contrasts}

In spite of rather homogeneous mineral chemistry, the spinel peridotites display heterogeneous major and trace element bulk rock compositions. They define $\mathrm{MgO}$ vs.
$\mathrm{SiO}_{2}$ and $\mathrm{FeO}_{\text {tot }}$ correlations similar to those documented in abyssal peridotites (Niu 1997; Niu et al. 1997) (Fig. 4), and attributed to olivine addition by melt migration through previously depleted mantle residues; the most $\mathrm{Mg}$-rich, $\mathrm{Si}$ depleted sample, farthest from any melting trend, is the harzburgite MM2/11 (Fig. 4). The decoupling between bulk rock and mineral chemistry is highlighted in an $\mathrm{Yb}_{\mathrm{N}}$ vs. $\mathrm{Ce}_{\mathrm{N}} / \mathrm{Yb}_{\mathrm{N}}$ diagram $\left(\mathrm{Yb}_{\mathrm{N}}\right.$ in the bulk rock vs. $\mathrm{Ce}_{\mathrm{N}} / \mathrm{Yb}_{\mathrm{N}}$ ratio in bulk rock and clinopyroxene) (Fig. 10). Melting trends reported in Fig. 10 show that increasing degrees of partial melting of a lherzolitic source produce progressive HREE and $\mathrm{Ce}_{\mathrm{N}} / \mathrm{Yb}_{\mathrm{N}}$ decrease in both bulk rock and clinopyroxene. Overall, the Mt.Maggiore spinel peridotites do not define such correlation. Rather, they display variable bulk HREE concentrations $(0.5-1.2 \times \mathrm{C} 1)$ at slightly variable LREE fractionation $\left(\mathrm{Ce}_{\mathrm{N}} / \mathrm{Yb}_{\mathrm{N}}=0.010-0.034\right)$. Peridotites MM2/10 and MM1/9 display bulk-mineral REE correlations roughly consistent with melting residues, whereas the largest deviation from melting trends is shown by spinel harzburgite MM2/11.

Modal compositions also diverge from those expected for melting residues. In Fig. 11a the modal olivine contents and cpx/opx ratios of spinel peridotites are compared with various melting trends (from Godard et al. 2000). Most MM spinel peridotites display enrichment in modal olivine (up to $75-85 \mathrm{wt} \%$ ) with respect to mantle residues; this feature has been documented in abyssal and ophiolitic peridotites (Niu 1997, 2004; Asimow 1999; Godard et al. 2000; Rampone et al. 2004; Seyler et al. 2007) and constitutes evidence of melt-rock interaction. Niu (1997, 2004) explained the modal olivine enrichment in abyssal peridotites as resulting from a process of olivine addition by melts migrating in the TBL. In the MM peridotites the increase in modal olivine is coupled to progressive decrease of the cpx/opx ratio, implying that the melt-rock reaction process also caused pyroxene dissolution, in agreement with microtextural evidence. Similar observations were made by Asimow (1999) and Rampone et al. (2004), who inferred that a process of equilibrium porous flow involving dissolution and precipitation reaction can explain, better than simple olivine addition, the major element and modal compositions of abyssal and Erro-Tobbio peridotites.

Further evidence that the MM peridotites (especially sample MM2/11) were variably modified by reactive porous flow is the overall lack of correlation between modal olivine contents and bulk Mg-number (Fig. 11b). In Fig. 11b, we also report computed trends (from Bodinier and Godard 2003) for partial melting, refertilization reactions (involving pyroxene crystallization) and reactive porous flow (involving olivine crystallization and pyroxene dissolution). As shown by melting trends, any partial melting process causes a concomitant increase in modal olivine and bulk $\mathrm{Mg} \#$ in the peridotite residues. In contrast, 
Table 6 Trace element compositions of minerals in gabbronoritic veinlets

\begin{tabular}{|c|c|c|c|c|c|c|c|c|c|c|c|c|c|}
\hline & $\begin{array}{l}\text { M10 } \\
\text { cpx core }\end{array}$ & $\begin{array}{l}\text { M10 } \\
\text { cpx rim }\end{array}$ & $\begin{array}{l}\text { M10 } \\
\text { opx int }\end{array}$ & $\begin{array}{l}\text { M10 } \\
\text { plag }\end{array}$ & $\begin{array}{l}\text { M13 } \\
\text { cpx core }\end{array}$ & $\begin{array}{l}\text { M13 } \\
\text { opx int }\end{array}$ & $\begin{array}{l}\text { M13 } \\
\text { plag }\end{array}$ & $\begin{array}{l}\text { M14 } \\
\text { cpx core }\end{array}$ & $\begin{array}{l}\text { M14 } \\
\text { cpx int }\end{array}$ & $\begin{array}{l}\text { M14 } \\
\text { cpx rim }\end{array}$ & $\begin{array}{l}\text { M14 } \\
\text { plag }\end{array}$ & $\begin{array}{l}\mathrm{MM} 2 / 5 \mathrm{~B} \\
\text { cpx core }\end{array}$ & $\begin{array}{l}\text { MM2/5B } \\
\text { plag }\end{array}$ \\
\hline Sc & 59 & 51 & 32 & - & 58 & 33 & - & 57 & 68 & 67 & - & 53 & - \\
\hline $\mathrm{Ti}$ & 1,802 & 1,912 & 851 & 96 & 1,751 & 1,168 & 145 & 1,725 & 2,278 & 2,517 & 142 & 1,590 & 83 \\
\hline $\mathrm{V}$ & 320 & 297 & 166 & 3 & 287 & 169 & 3 & 313 & 356 & 346 & 3.44 & 361 & 2.84 \\
\hline $\mathrm{Sr}$ & 1.27 & 1.51 & 0.01 & 25.2 & 2.32 & 0.03 & 31.0 & 1.60 & 1.80 & 1.43 & 31.1 & 1.46 & 28.9 \\
\hline $\mathrm{Y}$ & 15.2 & 15.5 & 3.19 & 0.18 & 14.9 & 3.74 & 0.21 & 14.4 & 23.0 & 28.3 & 0.31 & 10.5 & 0.14 \\
\hline $\mathrm{Zr}$ & 2.82 & 3.17 & 1.08 & 0.035 & 3.05 & 2.12 & - & 3.09 & 5.70 & 10.31 & - & 2.03 & - \\
\hline $\mathrm{La}$ & 0.014 & 0.005 & - & 0.010 & 0.021 & & 0.017 & - & 0.018 & 0.034 & 0.024 & 0.010 & 0.009 \\
\hline $\mathrm{Ce}$ & 0.13 & 0.17 & 0.00 & 0.06 & 0.15 & 0.01 & 0.11 & 0.19 & 0.21 & 0.36 & 0.12 & 0.15 & 0.06 \\
\hline $\operatorname{Pr}$ & 0.08 & 0.12 & 0.00 & 0.04 & 0.08 & 0.00 & 0.03 & 0.08 & 0.12 & 0.21 & - & 0.08 & 0.01 \\
\hline $\mathrm{Nd}$ & 0.86 & 1.16 & 0.03 & 0.14 & 0.82 & 0.05 & 0.24 & 0.88 & 1.33 & 2.35 & 0.23 & 0.69 & 0.09 \\
\hline $\mathrm{Sm}$ & 0.84 & 0.81 & 0.07 & 0.07 & 0.87 & 0.07 & 0.09 & 0.87 & 1.36 & 2.13 & 0.063 & 0.74 & 0.07 \\
\hline $\mathrm{Eu}$ & 0.19 & 0.37 & 0.02 & 0.20 & 0.32 & 0.04 & 0.22 & 0.41 & 0.48 & 0.58 & 0.24 & 0.33 & 0.16 \\
\hline $\mathrm{Gd}$ & 1.82 & 1.80 & 0.16 & 0.05 & 1.70 & 0.35 & 0.06 & 1.71 & 2.62 & 3.92 & 0.09 & 1.12 & 0.14 \\
\hline $\mathrm{Tb}$ & 0.32 & 0.39 & 0.05 & - & 0.36 & 0.06 & - & 0.41 & 0.52 & 0.76 & - & 0.25 & 0.01 \\
\hline Dy & 2.34 & 2.61 & 0.39 & 0.05 & 2.32 & 0.48 & 0.05 & 2.41 & 3.34 & 4.98 & 0.06 & 1.74 & 0.06 \\
\hline Ho & 0.53 & 0.55 & 0.13 & 0.00 & 0.55 & 0.15 & - & 0.57 & 0.70 & 1.10 & 0.01 & 0.43 & - \\
\hline $\mathrm{Er}$ & 1.56 & 1.92 & 0.43 & 0.01 & 1.48 & 0.46 & - & 1.58 & 2.05 & 3.05 & 0.02 & 1.16 & - \\
\hline $\mathrm{Tm}$ & 0.25 & 0.23 & 0.06 & - & 0.20 & 0.08 & - & 0.25 & 0.27 & 0.43 & - & 0.18 & - \\
\hline $\mathrm{Yb}$ & 1.52 & 1.20 & 0.49 & - & 1.42 & 0.49 & - & 1.56 & 1.85 & 2.80 & - & 1.00 & - \\
\hline $\mathrm{Lu}$ & 0.21 & 0.13 & 0.09 & - & 0.21 & 0.08 & - & 0.23 & 0.24 & 0.31 & - & 0.18 & - \\
\hline Hf & 0.21 & 0.38 & 0.07 & - & 0.25 & 0.14 & - & 0.26 & 0.36 & 0.87 & - & 0.20 & - \\
\hline $\mathrm{Ce}_{\mathrm{N}} / \mathrm{Yb}_{\mathrm{N}}$ & 0.024 & 0.039 & 0.001 & & 0.029 & 0.006 & & 0.032 & 0.031 & 0.045 & & 0.041 & \\
\hline $\mathrm{La}_{N} / \mathrm{Sm}_{\mathrm{N}}$ & 0.011 & 0.004 & & 0.103 & 0.016 & & 0.119 & & 0.009 & 0.010 & 0.081 & 0.009 & 0.088 \\
\hline
\end{tabular}

Trace element contents are given in ppm. All analyses by LA-ICP-MS

melt-rock interaction produces harzburgites and dunites with lower bulk Mg-number (at a given olivine modal proportion) than predicted by melting models (Bedini et al. 2003). In the MM spinel peridotites, bulk Mg-numbers define a rather narrow range $(0.898-0.905)$ in spite of large modal olivine variation (69-81 wt\%), and spinel harzburgite MM2/11 has the highest modal olivine content, thus plotting on the reactive porous flow trends.

\section{Inferences on the reactive porous flow event}

The least affected peridotites are represented by samples $\mathrm{MM} 2 / 10$ and MM1/9, in terms of both textural and geochemical features. Melt-rock interaction originated olivine-enriched "reactive" harzburgites, best represented by sample MM2/11. The open-system crystallization of migrating melts is indicated by the type of melt-rock interaction, which caused depletion rather then refertilization of the bulk system, thus implying that the fractionated melt was extracted from the solid, and the reaction likely occurred at high $T$, close to the peridotite solidus. Heating of the ambient peridotite was enhanced by melt percolation: this is consistent with the high equilibration $T\left(1,200-1,300^{\circ} \mathrm{C}\right)$ recorded in the most reactive peridotites (MM2/11, MM2/12).

Different hypotheses have been proposed concerning the timing and localization of the reactive porous flow event. In abyssal peridotites, Seyler et al. (2007) inferred that the melt-rock reaction started close to the peridotite solidus, and continued at relatively low $T$ in the TBL. Similar inference was made by Niu (1997, 2004), who considered the TBL as the logical place for post-melting refertilization or interaction between mantle residues and ascending melts. In the Othris peridotites, ascribed to a slowspreading ridge setting, Dijkstra et al. (2003), based on textural features similar to those observed in the MM spinel peridotites, argued that the reactive porous flow occurred when the peridotites were already part of the TBL or of basal part of the thermal lithosphere. A different scenario was envisaged for the Lanzo South and Erro-Tobbio peridotites (Piccardo et al. 2004, 2007; Piccardo and Vissers 2007), which represent subcontinental lithospheric mantle progressively exhumed during pre-oceanic lithosphere extension. These authors inferred that reactive percolation at spinel-facies conditions occurred at the expense of pristine lithospheric peridotites and was caused by upwards 


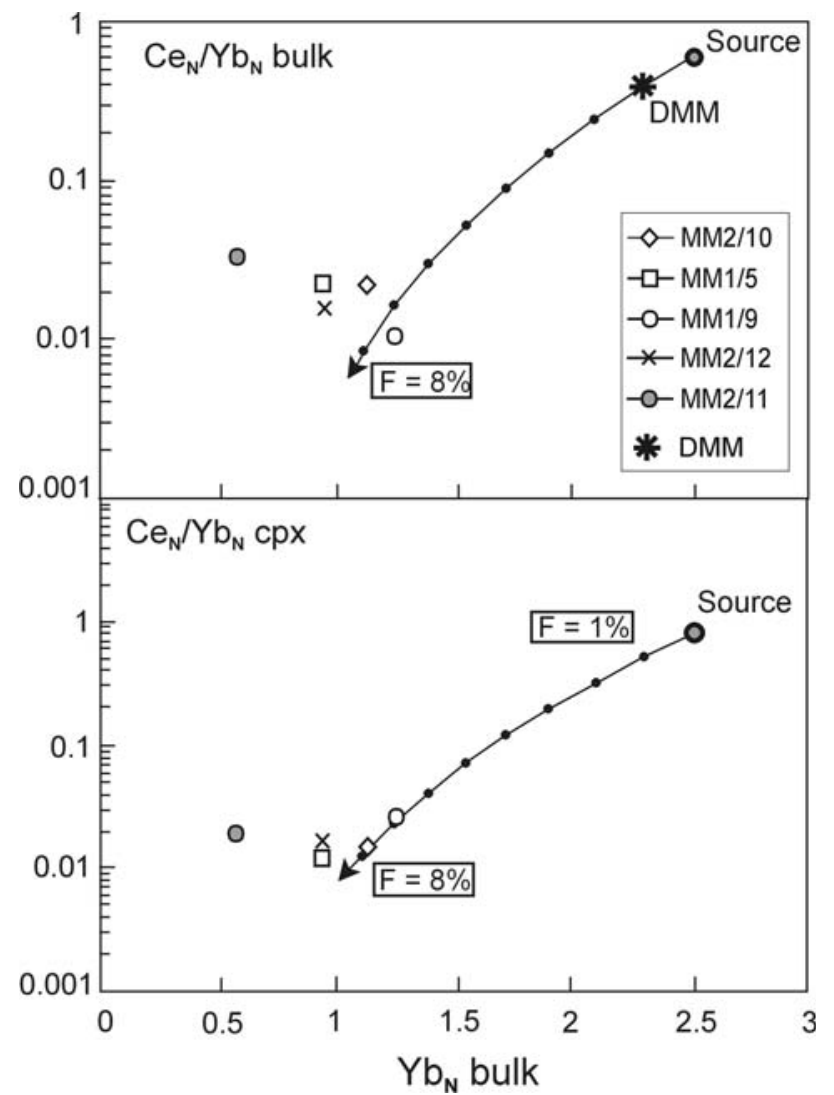

Fig. 10 Bulk rock $\mathrm{Yb}_{\mathrm{N}}$ contents vs. a Ce $\mathrm{Ce}_{\mathrm{N}} / \mathrm{Yb}_{\mathrm{N}}$ ratios in bulk rocks and b $\mathrm{Ce}_{\mathrm{N}} / \mathrm{Yb}_{\mathrm{N}}$ ratios in clinopyroxenes from the $\mathrm{MM}$ spinel peridotites. Also reported are computed fractional melting trends (model parameters as in Fig. 9), and the composition of the depleted MORB mantle (DMM) from Workman and Hart (2005)

migration of asthenospheric melts through the extending lithospheric mantle, which underwent thermo-chemical erosion and "asthenospherization".

Isotope studies on the MM ultramafics here investigated have shown that all the peridotites, i.e. spinel peridotites still resembling melting residues (MM1/9, MM2/10), reactive spinel peridotites (MM2/12) and plagioclase peridotites, posses similar ${ }^{147} \mathrm{Sm} /{ }^{144} \mathrm{Nd}$ and ${ }^{143} \mathrm{Nd} /{ }^{144} \mathrm{Nd}$ ratios which conform to the Jurassic linear array defined by intruded gabbroic rocks (Rampone 2004; E. Rampone et al., in preparation). This could reflect that partial melting, melt-rock interaction and melt intrusion stages were roughly coeval events occurred during the Jurassic. Combined textural evidence and thermometric estimates suggest that the reactive porous flow event occurred when the peridotites were already incorporated in the thermal lithosphere. The MM spinel peridotites could therefore represent residual mantle which was cooled and accreted at the basal part of the thermal lithosphere, and was subsequently thermally eroded and infiltrated by new ascending melts produced by asthenosphere upwelling during lithospheric extension.

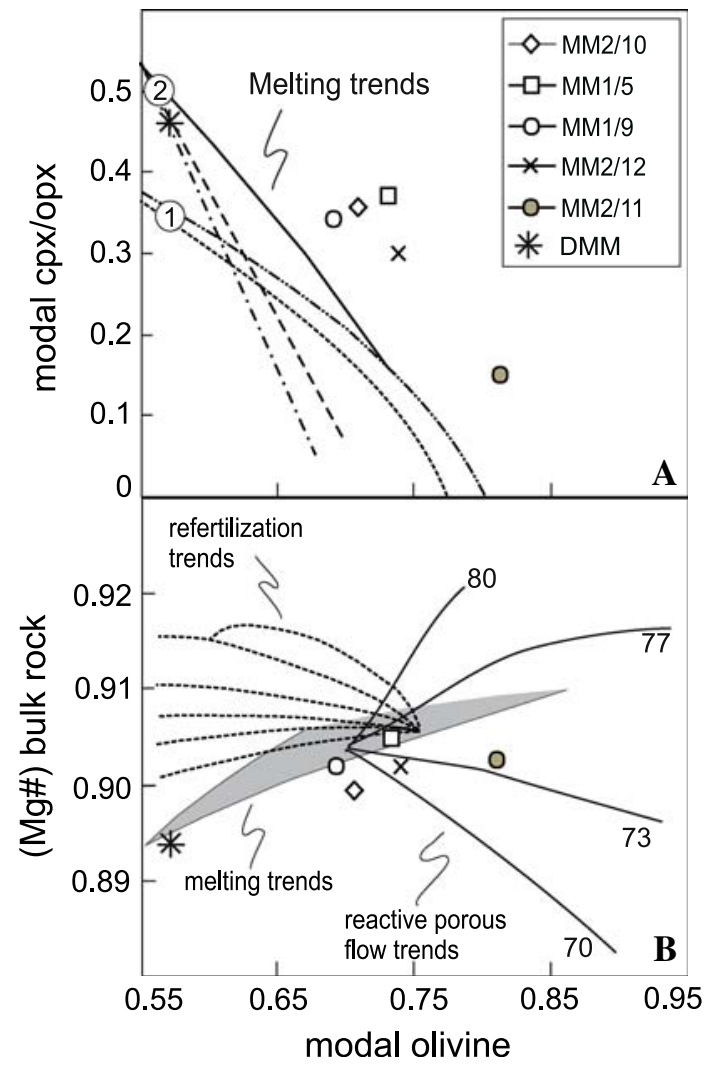

Fig. 11 a Modal olivine vs. modal cpx/opx and b modal olivine vs. $(\mathrm{Mg} \#)=[$ cationic ratio $\mathrm{Mg} /(\mathrm{Mg}+\mathrm{Fe})]$ in bulk rocks, for the $\mathrm{MM}$ spinel peridotites. a Also reported are various melting models from Niu (1997) (1, polybaric melting) and Walter et al. (1995) (2, isobaric melting at 11, 16, 17 kbar) (see Fig. 6 of Godard et al. 2000 for more explanation). b The grey field ("melting trends") refers to simple partial melting trends, assuming different melting reactions in the spinel-facies stability field (adapted from Bodinier and Godard 2003). "Reactive porous flow trends" (thick lines) were computed assuming a reactive porous flow process (involving olivine crystallization and pyroxene dissolution and variable infiltrating melt compositions, from $\mathrm{Mg \#}=70$ to $\mathrm{Mg} \#=80$ ), the "refertilization trends" (dashed lines) were computed assuming a refertilization process involving pyroxene-forming reactions (all trends are from Bodinier and Godard 2003, see this reference for details on the model parameters). The composition of depleted MORB mantle $(D M M)$ is from Workman and Hart (2005)

Trace element chemistry of clinopyroxenes in the most reactive peridotites indicate that migrating melts had a depleted compositions, probably produced by low-degree fractional melting. Percolation and interaction with depleted melts has been increasingly documented in ophiolitic and abyssal peridotites from slow- to very slow-spreading oceanic settings (Batanova et al. 1998; Seyler et al. 2001; Dijkstra et al. 2003; Barth et al. 2003; Borghini et al. 2007; Piccardo et al. 2007) and different hypotheses have been inferred for their origin: (1) melts which acquired the depleted signature by migration, extensive interaction and re-equilibration with depleted lithospheric mantle, (2) melts produced by shallow refractory peridotites, (3) melts 
originated as depleted final increments derived from underlying portions of the mantle, assuming a rather uniform melt production rate in the ascending mantle column.

Plagioclase peridotites: melt impregnation at shallower lithospheric depths

The Mt.Maggiore massif displays hectometer-scale areas where the spinel peridotites grade into plagioclase-enriched peridotites. The plagioclase-bearing peridotites in places preserve the "cooling textures" (opx + spinel symplectites) and the "olivine crystallization-pyroxene dissolution" microstructures indicative of melt-rock interaction stage 1 . A second stage of melt-rock interaction causing melt impregnation is primarily indicated by a significant plagioclase enrichment in the peridotites (modal plagioclase up to $11 \mathrm{wt} \%$ ) and by the development of peculiar microstructures: (1) partial dissolution and replacement of exsolved mantle clinopyroxene by unstrained opx + plag intergrowths, (2) crystallization of unstrained poikilitic orthopyroxene partially replacing mantle olivine, (3) crystallization of plag-rich gabbronoritic veinlets within the peridotite matrix. In terms of bulk rock chemistry, the most evident chemical changes in the impregnated peridotites are: (1) re-enrichment in fusible components $\left(\mathrm{Al}_{2} \mathrm{O}_{3}, \mathrm{CaO}\right)$ and development of high $\mathrm{Al}_{2} \mathrm{O}_{3} / \mathrm{CaO}$ ratios (up to 1.7) exceeding PM and DM values (see Fig. 4), (2) overall higher REE bulk concentrations (HREE up to $1.5 \times \mathrm{C} 1$ ) at constant LREE fractionation $\left(\mathrm{Ce}_{\mathrm{N}} / \mathrm{Yb}_{\mathrm{N}}=0.012-0.025\right)$, relative to spinel peridotites. These textural and chemical features indicate that the plagioclase-bearing melt-rock interaction stage was related to cooling and crystallization of fractionating melts within the peridotites, differently from the reactive porous flow process which modified the spinel peridotites. The occurrence of plagioclase as a crystallizing product, the preservation of significant chemical heterogeneity in minerals, and the style of melt-rock interaction (ruled by closed-system crystallization) demonstrate that the melt impregnation stage occurred when the spinel peridotites were located at shallower and cooler lithospheric depth, relative to the reactive porous flow stage.

Compositions of reacted clinopyroxenes within the impregnated peridotites were likely modified by crystallization of small trapped melt amounts (see later Discussion), and are therefore not reliable to estimate the compositions of impregnating melts. For this purpose, we will consider in the following the compositions of minerals in the gabbronoritic veinlets.

\section{Composition of impregnating melts}

Crystallization of orthopyroxene associated with plagioclase in the impregnated peridotites and in the gabbronoritic veinlets indicate the Si-rich opx-saturated composition of impregnating melts. However, high Mgnumbers coupled to high $\mathrm{Al}, \mathrm{Cr}$ contents and low incompatible trace element concentrations of both ortho- and clino-pyroxene in the gabbronoritic veinlets suggest that equilibrium melts had a rather primitive chemical signature. This implies that the opx saturation was not a consequence of melt differentiation via fractional crystallization, rather it was acquired by interaction of melts with the host peridotites (ruled by olivine crystallization and pyroxene dissolving reaction) during their upward migration. Peridotites were thus impregnated by opx-saturated melts, which locally reached clinopyroxene saturation and crystallized gabbronoritic veins.

Clinopyroxenes in the gabbronorites are chemically zoned: they exhibit trace element enrichment from cores to rims to interstitial grains. Similar chemical effects are documented in cumulates (Bédard 1994; Coogan et al. 2000; Charlier et al. 2005; Gao et al. 2007; Borghini and Rampone 2007) and are largely caused by in situ fractional crystallization of trapped melts (see the next paragraph). These studies have pointed out that, in cumulate rocks, only the cores of large cumulus crystals can be considered reliable to infer the compositions of equilibrium melts, because they are most likely unaffected by the trapped melts. We thus used the REE composition of clinopyroxene cores to derive the composition of impregnating melts. Computed melt compositions are shown in Fig. 12a and compared with the REE compositions of single melt increments produced by a fractional melting process (see caption for model details). In terms of LREE fractionation, they reflect single depleted melt increments $(6-7 \%$ fractional melting) rather than MORB-type aggregated melts. Similar LREE depletion is shown by calculated melts in equilibrium with the cores of orthopyroxene crystallized in the veinlets and as poikilitic crystals in the peridotites (Fig. 12a). It is remarkable however that computed melts show higher M- to H-REE concentrations relative to single 6-7\% depleted melt increments.

We stated above that the primitive, opx-saturated composition of impregnating melts indicate that they were modified during ascent by reactive porous flow through the lithospheric mantle. Different models have been proposed to test the chemical modifications of migrating melts during reactive porous flow (Kelemen et al. 1992; Vernières et al. 1997; Bodinier and Godard 2003). A simple approach, which implies attainment of equilibrium between percolating melts and the host crystal matrix, is the use of AFC equation (De Paolo 1981). Attainment of equilibrium during the melt impregnation stage is suggested by the smooth REE spectra of clinopyroxene in both impregnated peridotites and gabbronoritic veinlets. We therefore used the AFC model to test whether calculated REE 

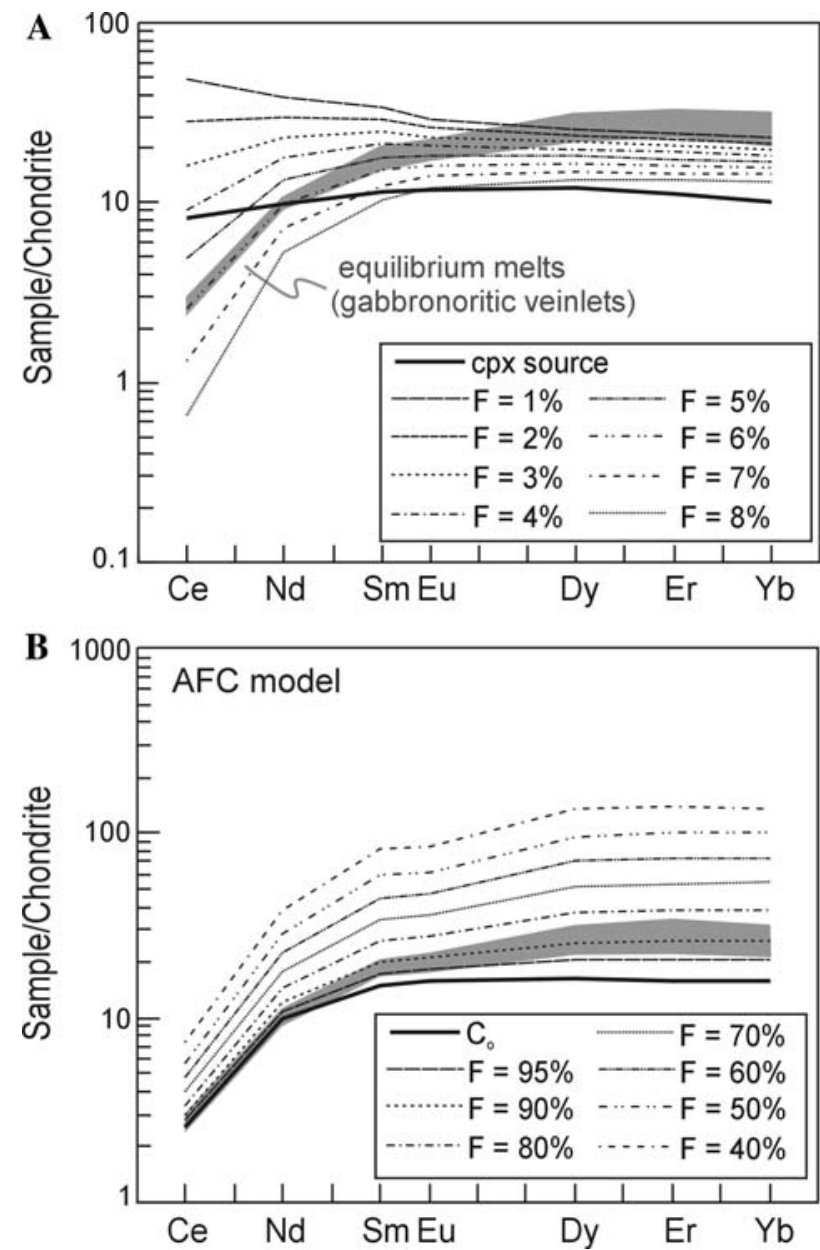

Fig. 12 a Chondrite-normalized REE spectra of single melt increments produced by variable degrees $(F)$ of fractional melting. Model parameters as in Fig. 9a. The grey field refers to the composition of computed melts in equilibrium with cores of clino- and orthopyroxenes in the plag-rich gabbronoritic veinlets and poikilitic orthopyroxene in the impregnated peridotites. b Chondrite-normalized REE abundances of modified melts computed by AFC model (De Paolo 1981) at decreasing melt mass $(F=95-40 \%)$. The initial melt composition $C_{\mathrm{o}}$ is the depleted melt increment produced by $6 \%$ fractional melting (see Fig. 12a). The model assumes that migrating melts assimilate pyroxenes $(\mathrm{Ma}=70 \%$ opx $+30 \% \quad \mathrm{cpx})$, and crystallize olivine ( $\mathrm{Mc}=100 \%$ olivine), and an $\mathrm{Ma} / \mathrm{Mc}$ ratio equal to 0.95 . The compositions of assimilated ortho- and clino-pyroxenes are from spinel peridotite MM2/10 (data reported in Tables 3, 5). Distribution coefficients from Suhr et al. (1998). Normalization factors as in Fig. 5

compositions of impregnating melts are consistent with the dissolution-precipitation reactions inferred to be responsible of their opx-saturated signature. Computed REE spectra of AFC modified melts at decreasing melt mass are shown in Fig. 12b. Modelling parameters are given in the figure caption. We assumed that migrating melts assimilated pyroxenes $(\mathrm{Ma}=70 \%$ opx $+30 \% \mathrm{cpx})$, and crystallized olivine $(\mathrm{Mc}=100 \%$ olivine), and we used ortho- and clino-pyroxene compositions of spinel peridotites MM2/10 as representative of the assimilated assemblage (Ma). AFC models were performed assuming different depleted melt increments produced by variable $(5,6$ and $7 \%$ ) fractional melting degrees as initial melt compositions, and different $\mathrm{Ma} / \mathrm{Mc}$ ratios. Overall, the results of geochemical modelling indicate that the inferred melt-rock interaction process does not cause significant changes in the LREE fractionation of modified melts, but a progressive increase in the M-H-REE contents (relative to the LREE) is observed at high $\mathrm{Ma} / \mathrm{Mc}$ ratios $(>0.90)$. Specifically, Fig. $12 \mathrm{~b}$ shows that the REE spectra of impregnating melts can be reproduced assuming a depleted melt increment produced by $6 \%$ fractional melting as initial melt composition, and an $\mathrm{Ma} /$ Mc ratio equal to 0.95 . In summary, impregnating melts are thought to have originated as depleted melt increments that were modified by melt-rock interaction with depleted peridotites under conditions of slightly decreasing melt mass, in agreement with previous work by Rampone et al. (1997). The opx-saturated signature of impregnating melts reflect a compositional feature acquired by reactive porous flow during migration from the melting region to rather shallow lithospheric depth at which impregnation occurred. Similar conclusions were drawn by Dijkstra et al. (2003), for plagioclase-rich impregnated peridotites of the Othris Massif (Greece).

\section{Chemical changes in minerals: evidence of trapped melt crystallization}

In the plagioclase peridotites melt-rock interaction caused systematic chemical changes in minerals correlated with microtexture: (1) Al decrease and Ti, REE, Zr, Y, Sc, V increase in core-rim traverses of "reacted" clinopyroxene, coupled to development of negative $\mathrm{Eu}_{\mathrm{N}}$ anomalies (Figs. 6, 7, 8), (2) similar REE variations in orthopyroxene crystallized as reaction rim around cpx, relative to orthopyroxene porphyroclasts and cores of poikilitic grains (Figs. 7, 8), (3) Ti and Cr\# enrichment in spinel (Fig. 9b). Consistent compositional variations are observed from cores to rims to interstitial clinopyroxene grains in the gabbronoritic veinlets. Similar mineral chemical modifications were previously documented in plagioclase-rich impregnated peridotites from the Alpine-Apennine system (Rampone et al. 1997; Piccardo et al. 2004, 2007; Borghini et al. 2007) and the Othris Massif (Barth et al. 2003; Dijkstra et al. 2003). In these studies, the trace element enrichment recorded by clinopyroxene was variably interpreted to reflect (1) interaction and equilibration with percolating melts which acquired a trace element enriched signature during open-system migration in the lithospheric mantle (Piccardo et al. 2004), (2) crystallization, within the peridotites, of cumulate crystals plus small trapped melt fractions (Rampone et al. 1997; Dijkstra et al. 2003), (3) 
crystallization of opx-saturated impregnating melts, assisted by high solid/melt partition coefficients for the REE (Piccardo et al. 2007). Piccardo et al. (2007) emphasized the role of high ${ }^{\text {solid/liquid }} D$, rather than trapped melt crystallization, based on the evidence that clinopyroxenes in the Southern Lanzo plagioclase peridotites, although invariably enriched, do not preserve any significant corerim chemical zonation within a single sample, and no compositional variations are observed between clinopyroxenes in different microstructural sites. By contrast, in the Mt.Maggiore peridotites preserved within-mineral chemical zoning and the striking correlation between chemical variations in clinopyroxene and its textural occurrence make a strong case that trace element enrichment at rims of reacted clinopyroxene porphyroclasts and in interstitial cpx grains within the gabbronoritic veinlets, was related to in situ melt-rock interaction and crystallization of trapped melts. This inference is based on the evidence that similar compositional variations are frequently observed in minerals from cumulate rocks (Bédard 1994; Charlier et al. 2005; Coogan et al. 2000; Gao et al. 2007; Borghini and Rampone 2007) and have been ascribed to in situ crystallization and interaction between cumulus minerals and interstitial melts.

An estimate of the amount of trapped melt (trapped melt fraction TMF) crystallized within a mineral matrix can be obtained using the Equilibrium Distribution Method (EDM) proposed by Bédard (1994). This mass balance model is based on the bulk rock trace element and modal compositions, and assumes that the trapped melt fraction is a phase crystallizing with ${ }^{\text {solid/liquid }} D=1$. It thus allows to calculate the changes in trace element composition of minerals assuming different TMF. Application of the Bédard's method to the gabbronorite M10 is shown in Fig. 13, which reports the REE-Zr spectra of clinopyroxene calculated assuming various amounts of TMF $(0,3$ and $5 \%$ ) and the overall variation range defined by clinopyroxene (core-rim traverses and interstitial grains) in the gabbronorite (see caption for more details). It is evident that computed clinopyroxene compositions are very sensitive to the TMF, and their REE-Zr spectra largely reproduce those of analysed clinopyroxenes. Also, it is remarkable that a small TMF $(<5 \%)$ is sufficient to generate a significant trapped melt effect, and to induce strong mineral chemistry modifications.

Similar results were obtained applying the EDM model to the plagioclase peridotites (Fig. 14a, see caption for model details). Again, the whole range of REE-Zr variation observed in clinopyroxenes is roughly reproduced assuming a very small interval $(0-3 \%)$ of trapped melt amount. It is noteworthy however that the Bédard's method in principle applies to cumulate rocks, and assumes that the assemblage of "cumulus minerals + trapped melt" acts as a closed

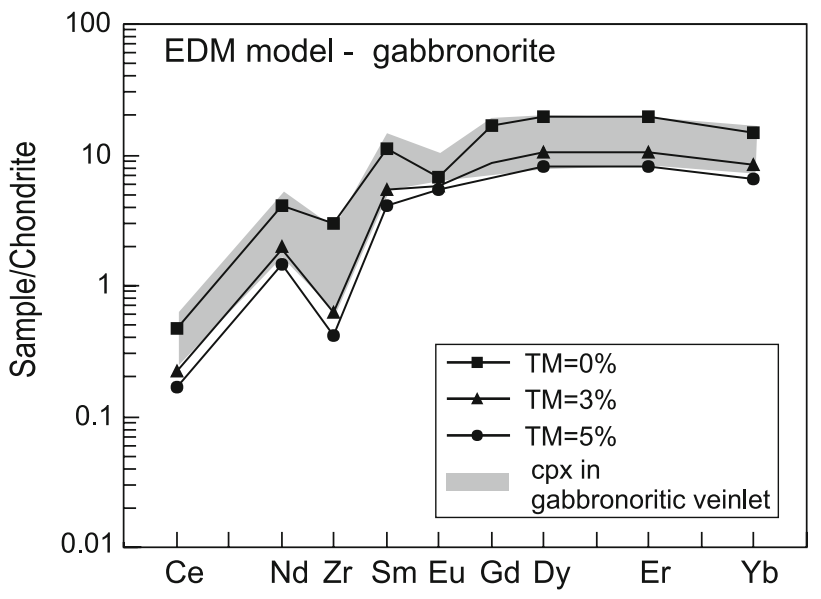

Fig. 13 Chondrite-normalized REE-Zr abundances of clinopyroxenes calculated with the Equilibrium Distribution Method (EDM, adapted from Bédard 1994) assuming trapped melts fractions (TMFs) of 0,3 and 5\%, and using the bulk rock REE abundance and modal composition of sample M14. Trapped melt modes were assumed as follows: (1) $0.01 \mathrm{cpx}, 0.01 \mathrm{opx}, 0.01$ plag for $\mathrm{TMF}=3 \%$; (2) 0.02 $\mathrm{cpx}, 0.01$ opx, $0.02 \mathrm{plag}$ for $\mathrm{TMF}=5 \%$. Crystal/liquid partition coefficients from Suhr et al. (1998). The grey field refers to the overall variational range defined by clinopyroxenes in the gabbronoritic veinlets. Normalization factors as in Fig. 5

system in which the trapped melt is initially in equilibrium with the cumulus minerals. This is not consistent with textural evidence in the plagioclase peridotites, which clearly indicates that the impregnating melts interact with mantle minerals, dissolving olivine and clinopyroxene and crystallizing orthopyroxene and plagioclase; this melt-rock interaction process can be more correctly modeled using the AFC equation (De Paolo 1981). We thus performed an AFC calculation to check whether clinopyroxene trace element variations in the plagioclase peridotites are consistent with the observed mineral reactions. In the modelling, we used the composition of melt calculated in equilibrium with clinopyroxene cores in the gabbronorite (see previous section) as representative of the initial composition of impregnating melts, and we assumed that the melt assimilated olivine and clinopyroxene $(\mathrm{Ma}=50 \%$ ol $+50 \%$ cpx) and crystallized plagioclase and orthopyroxene $(\mathrm{Mc}=70 \%$ plag $+30 \%$ opx $)$, according to textural observations. The REE-Zr compositions of clinopyroxenes in equilibrium with AFC modified melts, computed at progressively decreasing melt mass, are shown in Fig. 14b (see caption for model details). AFC calculations were performed at different $\mathrm{Ma} / \mathrm{Mc}$ ratios, and in Fig. $14 \mathrm{~b}$ are shown the results obtained at $\mathrm{Ma} / \mathrm{Mc}=0.7$, because higher $\mathrm{Ma} / \mathrm{Mc}$ values caused too high MREE/HREE fractionation in clinopyroxene. Similar to the trapped melt effect, the AFC process produces a progressive trace element increase in clinopyroxene, although preserving the observed REE-Zr spectra. Rather low $\mathrm{Ma} / \mathrm{Mc}$ ratios are consistent with the 


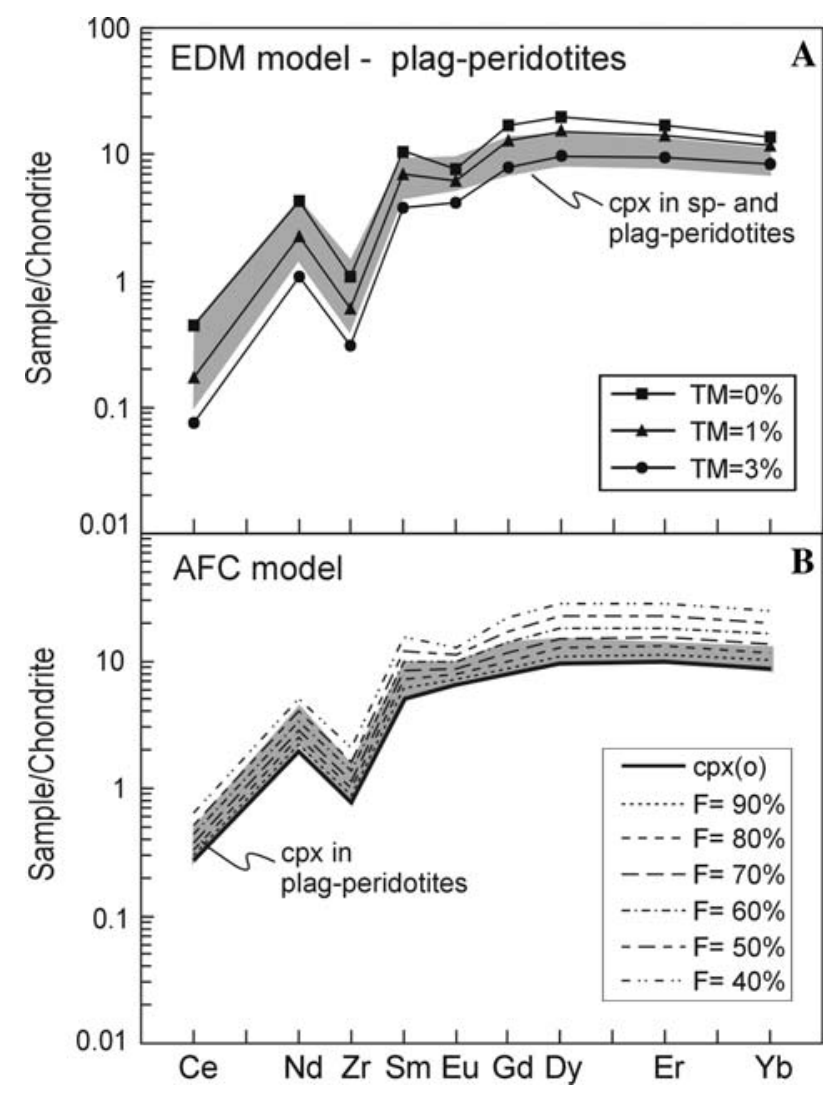

Fig. 14 a Chondrite-normalized REE-Zr abundances of clinopyroxenes calculated with the Equilibrium Distribution Method (EDM, adapted from Bédard 1994) assuming trapped melts fractions (TMFs) of 0,1 and $3 \%$, and using the bulk rock REE abundance and modal composition of sample MM1/10. Trapped melt modes were assumed as follows: (1) $0.005 \mathrm{cpx}, 0.005$ plag for $\mathrm{TMF}=1 \%$; (2) $0.005 \mathrm{cpx}$, 0.012 opx, 0.013 plag for $\mathrm{TMF}=3 \%$. Crystal/liquid partition coefficients from Suhr et al. (1998). The grey field refers to the overall variational range defined by clinopyroxenes in the spinel and plagioclase peridotites. b Chondrite-normalized REE-Zr abundances of clinopyroxene in equilibrium with modified melts computed by AFC model (De Paolo 1981) at decreasing melt mass $(F=90-40 \%)$. The initial clinopyroxene cpx $(0)$ is the average of clinopyroxene cores in the gabbronorites, considered as the most reliable to infer the initial composition of impregnating melts. The model assumes that impregnating melts assimilate olivine and clinopyroxene $(\mathrm{Ma}=50 \%$ $\mathrm{ol}+50 \% \mathrm{cpx})$ and crystallize plagioclase and orthopyroxene $(\mathrm{Mc}=70 \%$ plag $+30 \%$ opx $)$ according to textural observations, and an $\mathrm{Ma} / \mathrm{Mc}$ ratio equal to 0.70 . The composition of assimilated clinopyroxene is from spinel peridotite MM1/9 (the cpx pc in Table 3); the composition of assimilated olivine has been computed in equilibrium with clinopyroxene using crystal/liquid partition coefficients from Suhr et al. (1998). The grey field refers to the variational range defined by clinopyroxenes in the plagioclase peridotites. Normalization factors as in Fig. 5

style of melt-rock interaction, ruled by conductive cooling and close-system crystallization.

In summary, we infer that trace element enrichment observed in clinopyroxene from the plagioclase peridotites does not reflect a primary chemical signature of impregnating melts, rather it was caused by the concomitant effects of local melt-rock interaction at decreasing melt mass, and crystallization of small trapped melt fractions. The distinct "geochemical styles" of melt impregnation documented in the plagioclase-rich peridotites of the Alpine-Apennine system, i.e. homogeneous trace element enrichment in mantle pyroxenes with no preservation of chemical zoning (Lanzo South, North and Erro-Tobbio plagioclase peridotites; Piccardo et al. 2004, 2007; Piccardo and Vissers 2007), or within-mineral chemical zoning and correlation between chemical variations and microtexture (Mt.Maggiore peridotites; Rampone et al. 1997, this study) could reflect differences in the cooling rates between the two lithospheric environments at which the impregnation occurred, which could result from different thermal regimes, i.e. different lithospheric depths (shallower and colder in the case of Mt.Maggiore). This in turn could be related to different paleogeographic settings of the Lanzo, Erro-Tobbio and Mt.Maggiore peridotites in the Jurassic Ligurian Tethys ocean, the Mt.Maggiore peridotites representing a more internal, thinner and younger oceanic lithospheric mantle.

\section{Conclusions}

The Mt.Maggiore peridotites record a composite asthenosphere-lithosphere evolution, characterized by partial melting and subsequent multi-stage melt migration and interaction. Melt-rock interaction recorded by the spinel peridotites (stage 1) documents open-system melt migration by reactive porous flow at deep lithospheric levels, whereas the impregnation stage (stage 2) points to cooling and crystallization of migrating melts when the peridotites became part of colder and presumably shallower lithospheric environments. Impregnated peridotites preserve microtextural evidence of the previous sp-facies melt-rock interaction stage, thus suggesting that the peridotites were progressively uplifted in response to lithosphere extension and thinning. Migrating melts were likely produced by mantle upwelling and melting related to extension. In the two melt-rock interaction stages, percolating melts have similar LREE depleted compositions, consistent with depleted melt fractions produced by low-degree fractional melting. They could therefore represent last melt increments, produced by the ascending and melting asthenospheric mantle column, which were progressively modified from olivine-saturated to opx-saturated compositions, and caused different styles of melt-rock interaction depending on the lithospheric depths at which the interaction process occurred. The impregnation features recorded in the Mt.Maggiore peridotites correspond to the stage when percolating melts reached rather shallow lithospheric environments, where the competing effects 
between heating by melt percolation and cooling by conductive heat loss caused interstitial melt crystallization, forming cumulate minerals (plus minor amounts of trapped melt) within the peridotites. Overall, the results of this work point that MORB-type melt migration and meltperidotite interaction can be highly effective in producing large vs. small scale heterogeneities in the lithospheric mantle at extensional settings, and highlight the importance of combined microstructural and bulk/mineral chemistry investigations to distinguish between partial melting and melt-rock interaction chemical signatures.

Acknowledgments We acknowledge A. Zanetti (Pavia) and L. Negretti (Genova) for assistance with the SIMS, LA-ICP-MS and EDS analyses. J.-L. Bodinier (Montpellier) and M. Mazzucchelli (Modena) are greatly thanked for providing ICP-MS and XRF bulkrock analyses. J. Hoefs and an anonymous referee are gratefully acknowledged for constructive criticisms and suggestions. We acknowledge funding by the University of Genova and Italian PRINCOFIN to the project "The role of melt peridotite interaction in the modification and evolution of the lithospheric mantle".

\section{References}

Anders E, Ebihara M (1982) Solar system abundance of the elements. Geochim Cosmochim Acta 46:2363-2380

Asimow PD (1999) A model that reconciles major- and trace-element data from abyssal peridotites. Earth Planet Sci Lett 169:303-319

Baker MB, Beckett JR (1999) The origin of abyssal peridotite: a reinterpretation of constraints based on primary bulk composition. Earth Planet Sci Lett 171:49-61

Barth MG, Mason PRD, Davies GR, Dijkstra AH, Drury MR (2003) Geochemistry of the Othris ophiolite, Greece: evidence for refertilization? J Petrol 44:1759-1785

Batanova VG, Suhr G, Sobolev AV (1998) Origin of geochemical heterogeneity in the mantle peridotites from the Bay of Island ophiolite, Newfoundland, Canada: ion probe study of clinopyroxenes. Geochim Cosmochim Acta 62(5):853-866

Bédard JH (1994) A procedure for calculating the equilibrium distribution of trace elements among the minerals of cumulate rocks, and the concentration of trace elements in coexisting liquids. Chem Geol 118:143-153

Bedini RM, Bodinier J-L, Vernières J (2003) Numerical simulation of $\mathrm{Fe}-\mathrm{Mg}$ partitioning during melting and melt-rock interactions in the upper mantle. Geophys Res Abstr 5:13457

Bodinier J-L, Godard M (2003) Orogenic, ophiolitic and abyssal peridotites. In: Holland HD, Turekian KK (eds) Treatise on geochemistry, vol 2. Elsevier Science, Oxford, pp 103-170

Borghini G, Rampone E (2007) Postcumulus processes in oceanic-type olivine-rich cumulates: the role of trapped melt crystallization versus melt-rock interaction. Contrib Mineral Petrol 154:619-633

Borghini G, Rampone E, Crispini L, De Ferrari R, Godard M (2007) Origin and emplacement of ultramafic-mafic intrusions in the Erro-Tobbio mantle peridotites (Ligurian Alps, Italy). Lithos 94:210-229

Boudier F, Nicolas A (1977) Structural controls on partial melting in the Lanzo peridotites. In: Dick HJB (ed) Magma genesis: proceeding of the American geophysical union chapman conference on partial melting in the Earth's upper mantle. State Oregon Department Geology and Mineral Industries, vol 96. Portland, USA, pp 63-79
Brey GP, Kohler Y (1990) Geothermobarometry in four-phase lherzolites II. New thermobarometers, and practical assesment of existing thermobarometers. J Petrol 31:1353-1378

Cannat M, Bideau D, Hebert R (1990) Plastic deformation and magmatic impregnation in serpentinized ultramafic rocks from the Garrett transform fault (East Pacific Rise). Earth Planet Sci Lett 101:216-232

Charlier B, Auwera JV, Duchesne JC (2005) Geochemistry of cumulates from the Bjerkreim-Sokndal layered intrusion (S. Norway) Part II. REE and the trapped liquid fraction. Lithos $83: 255-276$

Chazot C, Charpentier S, Kornprobst J, Vannucci R, Luais B (2005) Lithospheric mantle evolution during continental break-up: the West Iberia non-volcanic passive margin. J Petrol 46(12):25272568

Constantin M, Hekinian R, Ackermand D, Stoffers P (1995) Mafic and ultramafic intrusions into upper mantle peridotites from fast spreading centers of the Eastern Microplate (South East Pacific). In: Vissers RLM, Nicolas A (eds) Mantle and lower crust exposed in oceanic ridges and in ophiolites. Kluwer, Dordrecht, pp 71-120

Coogan LA, Saunders AD, Kempton PD, Norry MJ (2000) Evidence from oceanic gabbros for porous melt migration within a crystal mush beneath the Mid-Atlantic Ridge. Geochem Geophys Geosyst 1(9). doi:10.1029/2000GC000072

Dal Piaz GV (1974) Le metamorphisme de haute pression et basse température dans l'evolution structurale du bassin ophiolitique alpino-apenninique, l'ère partie: considérations paléeogéeographique. Boll Soc Geol Ital 93:437-468

De Paolo DJ (1981) Trace elements and isotopic effects of combined wallrock assimilation and fractional crystallization. Earth Planet Sci Lett 53:189-202

Dick HJB (1977) Evidence of partial melting in the Josephine peridotite. Bull Oregon Dept Geol Mineral Ind 96:59-62

Dick HJB (1989) Abyssal peridotites, very low spreading ridges and ocean ridge magmatism. In: Saunders AD, Norry MJ (eds) Magmatism in the Ocean Basins, vol 42. Geological Society Special Publication, London, pp 71-105

Dijkstra AH, Drury MR, Vissers RML (2001) Structural petrology of plagioclase lherzolites in the West Othris Mountains (Greece): melt impregnation in mantle lithosphere. J Petrol 42:5-24

Dijkstra AH, Barth MG, Drury MR, Mason PRD, Vissers RML (2003) Diffuse porous melt flow and melt-rock reaction in the mantle lithosphere at the slow-spreading ridge: a structural petrology and LA-ICP-MS study of the Othris Peridotite Massif (Greece). Geochem Geophys Geosyst 4:1-24

Duran-Delga M (1984) Principaux traits de la Corse Alpine et corrélations avec les Alpes Ligures. Mem Soc Geol Ital 28:285329

Gao Y, Hoefs J, Hellebrand E, von der Andt A, Snow JE (2007) Trace element zoning in pyroxenes from ODP Hole 735B gabbros: diffuse exchange or synkinematic crystal fractionation. Contrib Mineral Petrol 153:429-442

Godard M, Jousselin D, Bodinier JL (2000) Relationships between geochemistry and structure beneath a paleo-spreading centre: a study of the mantle section in the Oman ophiolite. Earth Planet Sci Lett 180:133-148

Hebert R, Bideau D, Hekinian R (1983) Ultramafic and mafic rocks from the Garret transform fault near $13^{\circ} 30^{\prime} \mathrm{S}$ on the East Pacific Rise: igneous petrology. Earth Planet Sci Lett 65:107-125

Hekinian R, Bideau D, Francheteau J, Cheminee JL, Armijo R, Lonsdale P, Blum N (1993) Petrology of the East Pacific Rise crust and upper mantle exposed in Hess Deep (Eastern Equatorial Pacific). J Geophys Res 98:8069-8094

Hellebrand E, Snow JE, Dick HJB, Hofmann AW (2001) Coupled major and trace elements as indicators of the extent of melting in mid-ocean-ridge peridotites. Nature 410:677-681 
Hellebrand E, Snow JE, Hoppe P, Hofmann AW (2002) Garnet-field melting and late-stage refertilization in "residual" abyssal peridotites from the Central Indian Ridge. J Petrol 43(12):2305-2338

Hofmann AW (1988) Chemical differentiation of the earth: the relationship between mantle, continental crust and oceanic crust. Earth Planet Sci Lett 90:297-314

Jackson MD, Ohnenstetter M (1981) Peridotite and gabbroic structures in the Monte Maggiore massif, Alpine Corsica. J Geol 89:703-719

Johnson KTM, Dick HJB, Shimizu N (1990) Melting in the oceanic upper mantle: an ion microprobe study of diopsides in abyssal peridotites. J Geophys Res 95:2661-2678

Kelemen PB (1990) Reaction between ultramafic wall rock and fractionating basaltic magma, I, Phase relations, the origin of calc-alkaline magma series, and the formation of discordant dunite. J Petrol 31:51-98

Kelemen PB, Dick HJB (1995) Focused melt flow and localized deformation in the upper mantle: juxtaposition of replacive dunites and ductile shear zones in the Josephine peridotite, SW Oregon. J Geophys Res 100:423-438

Kelemen PB, Dick HJB, Quick JE (1992) Formation of harzburgites by pervasive melt-rock reaction in the upper mantle. Nature 358:635-641

Kelemen PB, Shimizu N, Salters JM (1995) Extraction of mid-oceanridge basalt from the upwelling mantle by focused flow of melt in dunite channels. Nature 375:747-753

Kelemen PB, Hirth G, Shimizu N, Spiegelman M, Dick HJB (1997) A review of melt migration processes in the adiabatically upwelling mantle beneath oceanic spreading ridges. Philos Trans R Soc Lond A 355:283-318

Kinzler RJ (1997) Melting of mantle peridotite at pressure approaching the spinel to garnet transition: application to mid-ocean ridge basalt petrogenesis. J Geophys Res 102:953-974

Klemme S, O'Neil HSC (2000) The effect of Cr on the solubility of $\mathrm{Al}$ in orthopyroxene: experiments and thermodynamic modelling. Contrib Mineral Petrol 140:84-98

Maaløe S, Scheie Å (1982) The permeability controlled accumulation of primary magma. Contrib Mineral Petrol 81:350-357

McKenzie D (1984) The generation and compaction of partially molten rocks. J Petrol 25:713-765

Menzies MA (1973) Mineralogy and partial melt textures within an ultramafic-mafic body, Greece. Contrib Mineral Petrol 42:273285

Menzies MA, Allen C (1974) Plagioclase lhezolite-residual mantle relationships within two Eastern Mediterranean ophiolites. Contrib Mineral Petrol 45:197-213

Molli G, Tribuzio R, Marquer D (2006) Deformation and metamorphism at the eastern border of the Tenda Massif (NE Corsica): a record of subduction and exhumation of continental crust. J Struct Geol 28:1748-1766

Müntener O, Piccardo GB (2003) Melt migration in ophiolitic peridotites: the message from Alpine-Apennine peridotites and implications for embryonic ocean basin. In: Dilek Y, Robinson PT (eds) Ophiolites in earth history, vol 218. Geological Society of Special Publication, London, pp 69-89

Müntener O, Pettke T, Desmurs L, Meier M, Schaltegger U (2004) Trace element and Nd-isotopic evidence and implications for crust-mantle relationships. Earth Planet Sci Lett 221:293-308

Nagata J, Goto A, Obata M (1983) The parabolic pattern of chromium partitioning observed between pyroxenes and spinel from ultramafic rocks and its petrological significance. Contrib Mineral Petrol 82:42-51

Nicolas A (1986) A melt extraction model based on structural studies in mantle peridotites. J Petrol 27:999-1022
Nicolas A (1989) Structure of ophiolites and dynamics of oceanic lithosphere. Kluwer Academic, Norwell, 367p

Niu Y (1997) Mantle melting and melt extraction processes beneath ocean ridges: evidence from abyssal peridotites. J Petrol 38:1047-1074

Niu Y (2004) Bulk rock major and trace element compositions of abyssal peridotites: implications for mantle melting, melt extraction and post-melting processes beneath mid-ocean ridges. J Petrol 45:2423-2458

Niu J, Langmuir CH, Kinzler RJ (1997) The origin of abyssal peridotites: a new perspective. Earth Planet Sci Lett 152:251265

Ohnenstetter D, Ohnenstetter M, Rocci G (1975) Tholeiitic cumulates in a high pressure metamorphic belt. Petrologie 1:291-317

Piccardo GB (2003) Mantle processes during ocean formation: petrologic records in peridotites from the Alpine-Apennine ophiolites. Episodes 26:193-199

Piccardo GB (2008) The Jurassic Ligurian Tethys, a fossil ultra-slow spreading ocean: the mantle perspective. In: Coltorti $M$, Gregoire M (eds) Metasomatism in oceanic and continental lithospheric mantle, vol 293. Geological Society Special Publication, London, pp 11-33

Piccardo GB, Vissers RLM (2007) The pre-oceanic evolution of the Erro-Tobbio peridotite (Voltri Massif - Ligurian Alps, Italy). J Geodyn 43:417-449

Piccardo GB, Müntener O, Zanetti A, Pettke T (2004) Ophiolitic peridotites of the Alpine-Apennine system: mantle processes and geodynamic relevance. Int Geol Rev 46:1119-1159

Piccardo GB, Zanetti A, Müntener O (2007) Melt/peridotite interaction in the Southern Lanzo peridotite: field, textural and geochemical evidence. Lithos 94(1-4):181-209

Quick JE (1981) The origin and significance of large, tabular dunites bodies in the Trinity peridotite, Northern California. Contrib Mineral Petrol 78:413-422

Rampone E (2004) Mantle dynamics during Permo-Mesozoic extension of the Europe-Adria lithosphere: insights from the Ligurian ophiolites. Period Mineral 73:215-230

Rampone E, Piccardo GB (2000) The ophiolite-oceanic lithosphere analogue: new insights from the Northern Apennines (Italy). In: Dilek Y, Moores EM, Elthon D, Nicolas A (eds) Ophiolites and oceanic crust: new insights from field studies and the oceanic drilling program, vol 349. Geological Society of America Special Paper, Boulder, pp 21-34

Rampone E, Piccardo GB, Vannucci R, Bottazzi P (1997) Chemistry and origin of trapped melts in ophiolitic peridotites. Geochim Cosmochim Acta 61:4557-4569

Rampone E, Romairone A, Hofmann AW (2004) Contrasting bulk and mineral chemistry in depleted peridotites: evidence for reactive porous flow. Earth Planet Sci Lett 218:491-506

Seitz HM, Altherr R, Ludwig T (1999) Partitioning of transition elements between orthopyroxene and clinopyroxene in peridotitic and websteritic xenoliths: new empirical geothermometers. Geochim Cosmochim Acta 63(23/24):3967-3982

Seyler M, Toplis MJ, Lorand JP, Luguet A, Cannat M (2001) Clinopyroxene microtextures reveal incompletely extracted melts in abyssal peridotites. Geology 29:155-158

Seyler M, Lorand J-P, Dick HJB, Drouin M (2007) Pervasive melt percolation reactions in ultra-depleted refractory harzburgites at the Mid-Atlantic Ridge, $15^{\circ} 20^{\prime} \mathrm{N}$ : ODP Hole $1274^{\circ}$. Contrib Mineral Petrol 153(3):303-319

Suhr G, Seck HS, Shimizu N, Gunther D, Jenner G (1998) Circulation of refractory melts in the lowermost oceanic crust: evidence from a trace element study of dunite-hosted clinopyroxenes in the Bay of Islands Ophiolite. Contrib Mineral Petrol 122:387405 
Tartarotti P, Vaggelli G (1995) Melt impregnation in mantle peridotites and cumulates from the Elba Island ophiolites, Italy. Mem Sci Geol 47:201-215

Tartarotti P, Susini S, Nimis P, Ottolini L (2002) Melt migration in the upper mantle along the Romanche Fracture Zone (Equatorial Atlantic). Lithos 63(3-4):125-149

Taylor WR (1998) An experimental test of some geothermometer and geobarometer formulations for upper mantle peridotites with application to the thermobarometry of fertile lherzolite and garnet websterite. N Jahrb Minerl Abh 172:381-408

Van der Wal D, Bodinier JL (1996) Origin of the recrystallization front in the Ronda peridotite by $\mathrm{Km}$-scale pervasive porous melt flow. Contrib Mineral Petrol 122:87-405

Vernières J, Godard M, Bodinier J-L (1997) A plate model for the simulation of trace element fractionation during partial melting and magma transport in the Earth's upper mantle. J Geophys Res 102:24771-24784 von der Handt A, Snow JE, Hellebrand E (2006) A quantitative assessment of melt origin versus subsolidus formation of plagioclase in Gakkel Ridge peridotites. Ofioliti 31(2):248-249

Walter MJ, Sisson TW, Presnall DC (1995) A mass proportion method for calculating melting reactions and application to melting of model upper mantle lherzolite. Earth Planet Sci Lett 135:77-90

Wells PRA (1977) Pyroxene thermometry in simple and complex systems. Contrib Mineral Petrol 62:129-139

Workman RK, Hart SR (2005) Major and trace element composition of the depleted MORB mantle (DMM). Earth Planet Sci Lett 231:53-72

Xu Y-G, Menzies M, Thirwall MF, Huang X-L, Liu Y, Chen X-M (2003) "Reactive" harzburgites from Huinan, NE China: products of the lithosphere-asthenosphere interaction during lithospheric thinning? Geochim Cosmochim Acta 67(3):487-505 